\title{
MARKET FAILURES AND THE UNDER-PROVISION OF TRAINING
}

\author{
GIORGIO BRUNELLO \\ MARIA DE PAOLA
}

CESIFO WORKING PAPER No. 1286

CATEGORY 4: LABOUR MARKETS

SEPTEMBER 2004

\footnotetext{
An electronic version of the paper may be downloaded

- from the SSRN website:

www.SSRN.com

- from the CESifo website:

www.CESifo.de
} 


\title{
MARKET FAILURES AND THE UNDER-PROVISION OF TRAINING
}

\begin{abstract}
This paper reviews both the theoretical underpinnings and the empirical evidence in support of the under-provision of training. While there is little if any evidence in support of underprovision because of liquidity constraints to the demand side of the market, there is evidence that employers provide and pay for general training, and that the provision of skills encourages labor turnover. The combination of these two facts suggests that the labor market provides less training than optimal. The balance of the existing empirical evidence suggests that policy discussions should focus on the employer rather than on employees. Therefore, we conclude our review by discussing policies which affect the employer' marginal benefits and marginal costs of training.
\end{abstract}

JEL Code: J24.

Keywords: training, efficiency, turnover.

\author{
Giorgio Brunello \\ Department of Economic Science \\ University of Padova \\ Via del Santo 33 \\ 35100 Padova \\ Italy \\ Giorgio.brunello@unipd.it
}

\author{
Maria De Paola \\ Department of Economics and Statistics \\ University of Calabria \\ Via Ponte Bucci \\ Arcavacatadi Rende, Cosenza 87036 \\ Italy \\ m.depaola@unical.it
}

Paper prepared for the Joint EC-OECD Seminar on Human Capital, Brussels, December 8, 2004. The ECHP data used in this paper are from the December 2001 release (contract 14/99 with the Department of Economics, University of Padova). 


\section{Executive Summary}

This paper reviews both the theoretical underpinnings and the empirical evidence in support of the under-provision of training. Under-provision in a market economy occurs when training is below its efficient level, which equalizes marginal social benefits to marginal social costs. With perfectly competitive labor markets, there is under-provision of training if individuals are liquidity constrained or if there are legal constraints, such as minimum wages, which do not allow workers to accept a sufficiently low initial wage. Under-provision also emerges when individuals are not fully rational or perfectly informed, for instance because they are too "present-oriented" or short-sighted to the point of not being able to perceive the benefits of training in terms of future earnings. Additional problems emerge if returns to training are uncertain, and when renegotiation between the parties takes place after the investment.

Labor market imperfections preclude the possibility that the investing individual can reap the full returns of her investment, and generate scope for underinvestment in human capital. Since general training often benefits future employers, who in imperfect labor markets do not pay for the full marginal product of workers, the level of investment undertaken by the current firm cannot be optimal. If quit rates are positive and firms in the market pay less than productivity, outside firms earn a profit from training, which is not considered by training firms when deciding whether to invest. This poaching externality reduces the incentive to train.

We argue in the paper that, if firms invest in general training, important evidence on under-provision can be obtained by looking at the relationship between investment in training and turnover. On the one hand, a positive relationship reduces the marginal benefits of training with respect to the first best, with negative effects on training. On the other hand, a negative relationship can compensate other sources of under-provision and close or even eliminate the gap between efficient and actual training outcomes. We find evidence of a statistically significant and positive relationship between employer - provided training and 
subsequent turnover for Denmark, Belgium, France and the UK. In the remaining countries the relationship is either not statistically significant or negative and statistically significant, as in the case of Finland. The evidence that in no country, except Finland, training significantly decreases the quit rate is suggestive of under-provision.

Policies which aim at increasing the level of training above the market level should be designed to affect either supply or demand, or both. In this review, we focus on supply policies, which directly affect firms but also have repercussions on the demand side. Broadly speaking, supply policies can affect employer provided training at the margin if they influence marginal benefits and marginal costs. We classify training policies as policies targeted to marginal benefits and policies targeted at marginal costs. Among the former we discuss payback clauses and apprenticeship contracts and among the latter levy/grant schemes, train or pay schemes and tax deductions.

These policies are motivated by under-provision, that is, by a level of training below the efficient level. A different issue is the equitable distribution of training opportunities. Since human capital is an important source of income and job satisfaction, an equitable allocation would require some redistribution in favor of groups of individuals who are less likely to be trained. The key question here is whether economic policy should try to correct outcomes - differences in training or to modify initial conditions which produce efficiently different outcomes - for instance differences in educational attainment. While important, this issue is beyond the scope of the current review.

Keywords: training, efficiency, turnover

JEL Codes: $J 24$ 


\section{Introduction}

Human capital, accumulated at school or in the labor market, is a key determinant of wages and employment opportunities (Lynch, 1992; Bishop, 1997, Booth et al. 1999, OECD, 1999; Dearden et al., 2000; Ok and Tergeist, 2003) and an important factor affecting economic growth (De la Fuente e Ciccone, 2002; OECD, 2001). Skill upgrading and the avoidance of skill obsolescence are relevant features of policies designed to increase labor market participation and the length of the working life and to reduce the social exclusion of particular groups and the consequences of population ageing.

Since many professional activities require skills that can only be acquired by direct experience, substantial investment in human capital takes place on-the-job rather than at schools or in specialized institutions. In this review paper we focus on training provided by firms. Many empirical studies show that there is substantial variation across countries and across socio-economic groups in training participation rates, with Nordic countries showing higher participation than Southern European countries (Ok and Tergeist, 2003) and low-educated and older workers generally participating less than other groups in training activities. Are these differences due to inefficiencies? More generally, do enterprises and workers invest enough in training? Although there is a large consensus in the economic literature on the importance of training, there is less agreement on whether the observed levels of investment in training are efficient.

The paper is organized as follows: in the first section we review the theoretical literature on under-provision; in the second section, we discuss the available empirical evidence, and in the last section we consider policy implications.

\section{The under-provision of training: theory}

Under - provision can only be defined with respect to a benchmark. The natural benchmark is the efficient level of training, which maximizes total output net of training costs. Equality of (private and social) marginal benefits and 
marginal costs does not imply that the efficient level of training is the same across different groups of individuals or countries. For instance, the poorly educated may face higher training costs because education and training are complements. Given marginal benefits, this group should receive less training. Therefore, the observation that the poorly educated receive less training than the better educated is not by itself evidence of inefficient under-provision. However, if the objective function pursued by the policy maker is a social welfare function rather than simply net output, and if the social planner cares about equality, then a significant dispersion of training across groups is not socially optimal even if it maximizes net output.

Of course, the level of training of individuals with lower educational attainment might be depressed below the first best level by other factors, such as higher turnover rates and more binding liquidity constraints. Similarly, some countries might invest too little in training because of labor market institutions. In these situations we have a case for under-provision. Inefficiencies can occur because of externalities, so that the private and the social benefits of training do not coincide. One possibility is that training an employee not only increases her productivity, but also the productivity of co-workers. The size of these externalities can vary across industries and local labor markets.

In this section we organize the review of the existing theories of under provision in two sub- sections, which cover perfectly and imperfectly competitive labor markets respectively.

\subsection{Perfectly competitive labor markets}

Becker, 1962, develops the dominant economic framework for the analysis of the investment in human capital when labor markets are perfectly competitive. The distinction between firm specific and general human capital plays a crucial role in defining who bears the investment cost. Since the investment in general human capital increases the recipient's productivity in all firms operating in the market, the firm currently employing the worker will not be prepared to finance 
this kind of investment in the absence of an enforceable contract. Because workers fully capture the benefits of training via higher wages, they will undertake the efficient level of investment in general skills and pay for it either directly or by accepting lower wages during the training period.

When training is firm specific, the costs and revenues are shared by the worker and the firm (Becker, 1964; Hashimoto, 1981). This result is based on the fact that the investment is lost if the worker and the firm separate after training. In contrast with the case of general training in a perfectly competitive labour market, this creates a wedge between the worker's productivity - which increases with training - and her outside option - which does not. To avoid quits the firm is willing to pay the trained worker a wage higher than her outside option, but below the worker's productivity. Therefore, the optimal contract implies that costs are shared as well.

Hashimoto, 1981, formally shows that the shares of cost paid by the firm and the worker depend on the relationship between quit rates and wages, layoff rates and profits, and on other variables such as the cost of funds and the attitude toward risk of the parties involved. He also shows that the level of training investment is ex-ante efficient, even in the presence of ex-post inefficient turnover. In the starting period the firm and the worker choose the level of specific training to maximize their expected net returns. With the assumption of free entry and in the absence of externalities this choice leads to efficient investment.

In this framework the efficient level of training depends on marginal costs and returns. Conditional on benefits, subjects who bear lower marginal training costs undertake higher investments. According to Rosen, 1976, Mincer, 1962, and Heckman, 2000, education plays an important role in providing basic skills, and improves the ability of individuals to learn other competencies in a variety of professional fields. Since learning begets learning, there is complementarity between education and training. A consequence of complementarity is that better educated individuals are more involved in both general and specific training, with undesirable implications for the equity of labor market outcomes: rather than 
compensating the existing differences produced by educational attainment, training widens these differences.

Notice, however, that a substitution effect between education and training cannot be excluded. If a given level of human capital is required for a job, this level could be attained either by providing more formal education or by on - the job training. The distinction between more formal off - the - job training (OFFJT) and on - the - job training (OJT) appears to be crucial when discussing the relationship between education and training. Lynch, 1992, uses US data and finds that education is positively and significantly related to the former type of training, but unrelated to the latter. Focusing on the concept of over-education, Sicherman, 1990, finds that over-educated individuals receive less OJT than individuals with lower education and interprets this result as evidence that education and OJT are substitutes in the production of human capital. Since over-educated workers are more likely to quit and move to a more suitable job, employers are less willing to train them in firm - specific skills. Hersch, 1991, obtains similar results and argues that the over-educated are less willing, or less able, to learn than individuals with the suitable level of education. Finally, Ariga and Brunello, 2003, study a sample of Thai and Filipino workers and find evidence that the complementarity between education and training is limited to OFFJT.

Another important aspect in the determination of the efficient level of training investment is the temporal horizon. Training returns accrue to the parties for a shorter period when subjects involved in training activities are older. On the one hand, older individuals should invest less in training than younger workers. On the other hand, older employees may suffer of education obsolescence. If education and training are complements, education obsolescence should generate less training for the old; if they are substitutes, older workers should be trained more to compensate for the decline in their human capital.

The length of the period during which skills acquired through training are used productively depends not only on the recipient's age but also on her labor market status. Acquired skills can be used in the production process only when the trained worker is employed. Therefore, individuals who expect to be 
unemployed some time in the future are less willing to invest in training. This implies that workers with temporary contracts invest less in training compared to workers with long-term contracts.

These considerations suggest that when training costs and benefits are heterogeneous the efficient level of training can vary across different groups, without any implication for under-provision. With perfectly competitive labor markets, there is under-provision of training if individuals are liquidity constrained (problems related to the capital market) or if there are legal constraints, such as minimum wages, which do not allow workers to accept a sufficiently low initial wage. Under-provision also emerges when individuals are not fully rational or perfectly informed, for instance because they are too "present-oriented" (high discount rate) or short-sighted to the point of not being able to perceive the benefits of training in terms of future earnings. These problems might be more relevant for certain groups of workers than for others. For example, low-income workers might be particularly affected by credit constraints, or might be unable to collect information about training returns.

Additional problems emerge if returns to training are uncertain, either because of shocks to the demand of particular competencies or because of uncertainty about the ability to acquire a certain qualification or skill level. Since workers are unlikely to obtain insurance against these types of risk they may be discouraged to invest in training (Layard, Robinson and Steedman, 1995).

\subsubsection{Renegotiation}

With perfectly competitive labor markets, an inefficient level of training can also occur if renegotiation between the parties takes place after the investment. When labor contracts cannot be committed upon ex-ante, renegotiation after the investment reduces the ex-ante incentive to invest (hold up). These problems of opportunism have been considered both in relation to specific investments (Williamson, 1975; Hashimoto, 1981; Prendergast, 1993; Kahn and Huberman, 1988; MacLeod and Malcomson, 1993) and in relation to investments in general 
human capital financed by workers (Acemoglu and Pischke, 1999a; Malcomson, Maw and McCormick, 2000).

Renegotiation by the employer discourages workers to invest in firm-specific skills, since these skills have no value outside the firm that currently employs them. This hold-up problem may be solved by reputation mechanisms or by contractual forms such as 'up-or-out' practices (Kahn and Huberman, 1988) and 'up-or-stay' promotion rules (Prendergast, 1993). Up-or-out contracts establishing that after an initial training period the firm must decide whether to "promote" the worker - and to award him a higher wage - or to fire him, guarantee efficient provision. If the wage paid after the training period is larger than the productivity of an untrained worker and smaller than the productivity of a trained one, the firm will be interested in promoting only those workers who invested in training. Nevertheless, if workers are heterogeneous and choose different levels of investment, it could be convenient for the firm to fire the workers who invested too little. This behavior may prevent the realization of efficient investment. Problems emerge also with up-or-stay contracts, which establish that workers who invest will be promoted while those who do not invest will retain their initial position, since their feasibility depends both on whether firms can attach wages to tasks and on whether the production technology allows the credible assignment of workers to tasks.

Investment in general human capital financed by the worker can induce firms to be opportunistic in their effective provision of training level and quality. Since training activities are characterized by imperfect observability and verifiability, their provision generates a classical moral hazard problem: the firm is tempted to pocket the wage reduction accepted by the worker without providing the contracted training or by supplying low quality training. Acemoglu and Pischke (1999a) argue that this problem may explain why the financing of general training is carried out by firms rather than by workers. They maintain that: "many skills are best learned by on-the-job training, combining production, learning-bydoing, and mentoring by more experienced colleagues. However, the employment relation gives the control over the worker's time to his employer. It is therefore 
possible for a firm to pay a low wage with a training promise, and then use the worker in regular production activities. This possibility could be avoided if what constitutes training were easily observed by courts, so that employment contracts could unambiguously specify the training obligations of the employer. Nevertheless, since important parts of the training program are intangible, involving mentoring, advice and practice, it is quite hard to specify them in advance and monitor the firm's compliance in individual cases. [...] We therefore view the contracting difficulties between firms and workers as an additional constraint on workers' ability to buy training in the workplace" [Acemoglu and Pischke, 1999a, p. 118].

Referring to the difficulty of verifying training activities, Malcomson, Maw and McCormick, 2000, argue that, since workers are imperfectly informed and firms are heterogeneous with respect to training costs, a problem of adverse selection might emerge, so that firms with high training costs might pocket the wage reductions accepted by workers without fulfilling their training promises, thereby discouraging workers from investing in human capital, even in the absence of capital market imperfections.

De Paola and Scoppa, 2001, show that with up-or-out contracts the firm's incentive to cheat on the provision of training is restrained by the cost it will incur in having to fill a new vacancy following its separation from the worker. Since this cost depends on labor market conditions, the interest in cheating when labor markets are tight is limited. On the other hand, firms have little incentive to honestly provide training in markets characterized by a high level of unemployment.

In addition, difficulties in measuring and verifying human capital investment may aggravate the conflicting interests of employers and employees concerning the type of skills (general or specific) to be provided (Stevens, 1994; Barron et al., 1997). Workers might be discouraged to invest in human capital since they are skeptical about the skills provided by the firm being sufficiently general to ensure a high productivity and wages in other firms. 


\subsection{I mperfectly competitive labor markets}

New sources of inefficiency have recently been stressed by a number of papers, which consider training when labor markets are not perfectly competitive. In this environment, firms may be willing to bear some or all the costs of providing general training if the increase of productivity induced by training is higher than the wage increase, that is, if there is wage compression. The divergence between productivity and wages as firms invest in training might arise for several reasons, including mobility costs, search and matching frictions, the complementarity between general and specific skills, and asymmetric information. As reviewed by Leuven, 2002, we can distinguish between two cases of information asymmetries: first, the training firm is better informed than the market about the skills of its employees. Second, the training firm is better informed about the abilities of its workers, which gives rise to adverse selection. All these imperfections reduce the outside option of workers investing in training. As shown by Acemoglu and Pischke, 1998, 1999a, 1999b, 2003, they turn general skills into de facto specific skills.

Since the existence of labor market imperfections precludes the possibility that the investing individual can reap the full returns of her investment, there is scope for under-investment in human capital. It is important to notice that the firm's monopsonistic power might differ across different types of workers. For example, some workers might be more affected by adverse selection problems or, due to the type of tasks they manage, might have a more firm-specific human capital. Better educated workers can also have highly dispersed abilities - because acquiring education not only improves skills but also makes them more variable which, in the case of adverse selection problems, translate into lower outside options and in a higher incentive for firms to invest in their human capital. Booth and Zoega, 2000, show that firms' incentives to invest in general training are increasing in task complexity. Workers' heterogeneous observable innate ability affects the variety of tasks, which can be performed within a firm and generates monopsony power to firms with a 'better' workforce. Since the degree of 
monopsony power is increasing in task complexity, firms with a workforce involved in more sophisticated tasks are more willing to finance general training.

\subsubsection{Turnover and poaching}

Employees with higher turnover rates are less likely to receive employer provided training. In addition, (general) training itself can increase turnover by increasing productivity in other firms. Since general training often benefits future employers, who in imperfect labor markets do not pay for the full marginal product of workers, the level of investment undertaken by the current firm cannot be optimal. If quit rates are positive and firms in the market pay less than productivity, outside firms earn a profit from training, which is not considered by training firms when deciding whether to invest. This poaching externality reduces the incentive to train (see Stevens, 1996; Katz and Zidermann, 1990) ${ }^{1}$.

To illustrate, assume that firms are identical and that individuals live and work for two periods. Training takes place during the first period, when both productivity and wages are equal to zero. Productivity and wages in the second period are denoted respectively by $y$ and $w$. For the sake of simplicity, we assume a discount factor equal to one and that the investment is totally financed by the employer. Optimality requires choosing an amount of training such as any further increase in investment would imply a marginal increase in output smaller than the corresponding marginal increase in costs:

$$
y^{\prime}(s)=c^{\prime}(s)
$$

\footnotetext{
1 The view that turnover might generate under-provision of training when firms invest is not shared by Moen and Rosen, 2002, who argue that efficiency can be preserved if firms and workers are able to write long- term contracts and to contract efficiently. This is interesting in principle but questionable in practice.
} 
Privately optimal training investment $\mathrm{s}$ is decided by each firm in the market to maximize the following profit function, where $q$ is the exogenous probability of separation

$$
(1-q)[y(s)-w(s)]-c(s)
$$

Therefore profit maximization implies choosing a level of training such as the increase in returns, which occur only with probability (1-q), is equal to the increase in costs:

$$
(1-q)\left\lfloor y^{\prime}(s)-w^{\prime}(s)\right\rfloor=c^{\prime}(s)
$$

where the primes are for first derivatives, that is the marginal increase in productivity and costs induced by a marginal increase in the training investment. The comparison of [1] and [3] shows that each firm in this market under-invests in training if $w^{\prime}(s)>0$ - that is if wages increase with training - because it cannot reap all the returns to the training investment. Moreover, training is negatively affected by the probability of quitting $\mathrm{q}>0$ and by poaching, which occurs when the productivity after training at the new firm is higher than the outside option.

Let now suppose that both the firm and the worker invest in training and let the share of training costs born by the employee be $\sigma \in(0,1)$. We also assume that the wage paid to the trained worker is equal to $w(s)=\beta y(s)$. While the first best still require that [1] holds, the firm's choice is given by the condition

$$
(1-q)\left\lfloor y^{\prime}(s)(1-\beta)\right]=(1-\sigma) c^{\prime}(s)
$$

and the worker's choice satisfies

$$
\beta y^{\prime}(s)=\sigma c^{\prime}(s)
$$


Since the total marginal returns of training of both the firm and the worker are equal to $y^{\prime}(s)[1-q(1-\beta)]$, the efficient solution can be reached either with $\mathbf{q}=0$, or with $\beta=1$. In the latter case the employee bears all the costs and reaps all the returns to training. Therefore, $s$ must be equal to 1 and we are back to Becker's case. In the unlikely case where $0<\beta=\sigma<1$, the worker has an incentive to invest efficiently but the firm still under-invests. The reason is that turnover, by creating positive training externalities, generates under-investment in general training (Acemoglu, 1997) ${ }^{2}$.

With investing firms, training is lower than the first best, and lower than [4], if employees are more likely to quit after training, that is $q^{\prime}(s)>0$, perhaps because their attained higher competencies increase their outside option, or if training increases the probability that trained workers find a new job after losing or leaving their current job. Since a higher re-employment probability increases the reservation wage and the worker's bargaining power, firms may be less willing to invest. The hazard rate from unemployment and the risk of poaching often varies across local labor markets. Ceteris paribus, we expect that firms located in a dense area with a strong industrial specialization have lower incentive to train than other firms, because of the higher turnover and poaching threat. However, as argued by Brunello and Gambarotto, 2004, and Brunello and De Paola, 2004, this local negative effect can be offset if denser areas generate positive pooling externalities associated to the flow of new ideas and to innovation, and these ideas and skills are complements. ${ }^{3}$

Other authors have suggested that training may reduce separation rates. According to Jansen, 1998, skills acquisition in a firm determines not only an increase in productivity, but also a reduction in the probability of separation.

\footnotetext{
${ }^{2}$ An alternative view has been offered by Booth and Zoega, 1999, who have argued that when there is uncertainty about future productivity, a higher quit rate reduce the importance of future flows and the option value of waiting rather than training.

3 Local economic conditions may influence training also through other channels. According to Acemoglu and Pischke, 1999, a high unemployment rate, by reducing wages, induces higher training investments by firms. However, since local unemployment also increases the availability of skilled employees in the local labor market, it allows firms to save on training costs by directly hiring an unemployed worker (see Brunello and Medio 2001, Barron, Black, and Loewenstein 1989, Stevens 1994).
} 
Hence, skilled workers, who can afford higher flexibility, are less subject than unskilled workers to separations induced by negative shocks.

We conclude that, if firms invest in general training, important evidence on under-provision can be obtained by looking at the relationship between investment in training and turnover. On the one hand, a positive relationship reduces the marginal benefits of training with respect to the first best, with negative effects on training. On the other hand, a negative relationship can compensate other sources of under-provision and close or even eliminate the gap between efficient and actual training outcomes.

\subsubsection{The role of labor market institutions}

The interest of firms to finance general skill acquisition by workers is greater when, as a result of monopsonistic power, the wage structure is more compressed. In the non-competitive labor market approach wage compression might be induced by institutional features, such as minimum wages and union wage bargaining, with theoretical predictions that are in sharp contrast with those derived from Becker's analysis.

For example, unionization can improve the commitment on wage contracts and reduce the hold up problem, thereby increasing training (Ryan, 1994). Unions may encourage training also because they play a relevant role in reducing labor turnover (Blau and Kahn, 1983; Freeman and Medoff, 1984, Booth and Chatterji, 1998). Moreover, if unions are industry wide, they can help internalizing poaching externalities (Booth, Francesconi and Zoega, 2003). Similarly, by reducing the dispersion of wages between trained and un-trained employees, unions can encourage firms to fund general training investments ${ }^{4}$.

\footnotetext{
4 Arulampalam and Booth, 1998, investigate the nexus between work-related training and labor market "flexibility" and suggest that there is a trade-off between expanding marginal forms of employment and expanding the proportion of the workforce getting work-related training. Therefore, the emphasis on the need to increase flexibility in the labor market might not be compatible with the increase in the stock of work-related skills by workers.
} 
A subtler view on the positive role of unions has been offered by Bhashkar and Holden, 2003, who argue that, if firms cannot differentiate wages within skill levels according to ability, perhaps because of unions, the employer can use training as a tool to attract and compensate abler workers, who are promoted to jobs requiring more sophisticated competences. With restraint on wage differentiation, training acts as a screening device. A similar point in the context of temporary help firms has been made by Autor, 2001.

On the negative side, unions may want to push for equality in the provision of training, with negative consequences on overall training investment, which goes beyond the training of the less advantaged groups. In addition, unions often oppose the introduction of new technologies requiring skill up-grading and by so doing indirectly oppose training.

According to Acemoglu and Pischke, 1999, a positive effect on training may also derive from minimum wages. Since firms have to pay the minimum wage even to their unskilled workers, rents from the employment relationship are eroded, and in order to restore such rents firms need to invest in training to increase the productivity of less skilled workers. Other authors, for example Jansen, 1998, and Fella, 2000, identify a positive relationship between the presence of firing costs and the investment in training by firms. Jansen, 1998, assumes that training reduces the probability of separation between workers and firms and shows that the payment of training costs by firms may represent a strategy to reduce turnover and firing costs. Fella considers the effect on training produced by institutional regulations, which establish a firing cost to be paid when the employment relationship is interrupted. He shows that, since investment in general training increases the worker's productivity outside the training firm, the latter might be interested in investing in training to save firing costs in the case of dismissals. The reason is that the firing cost is bargained between the parties, and is lower the higher the outside option available to the worker. Fella's model predicts a positive correlation between investment in general training and the strictness of employment protection rules. 


\subsubsection{Externalities and coordination problems}

Another source of under-investment is the co-ordination problems between workers and firms, which are often originated by decisions taken before entering the labor market. Firms invest in new technologies and workers in human capital, and these investments are linked by a complementary relationship: workers' returns to the investment in skills depend upon firms investing in the technology which requires these skills, and firms' returns to investment in the new technology depend upon the existence of an adequate supply of skilled workers. Scarce human capital generates high costs of posting skilled job vacancies and induces firms to employ technologies demanding low skills, which in turn leads to workers not investing in training.

Following this line of reasoning Snower, 1996, models the emergence of low skills - bad jobs trap characterized by persistent low productivity levels and under-investment in training. In this situation the social returns to posting skilled job vacancies and investing in training are higher than private returns. This is because a skilled job vacancy increases the probability that skilled workers find a good job and consequently raises the expected returns to training. On the other hand, investing in training increases the probability of filling a skilled vacancy and therefore raises the returns of creating skilled jobs. These network externalities create the possibility of multiple equilibria that can be ranked according to an efficiency criterion: a "high" equilibrium with high job creation and high training, and a "low" equilibrium with low job creation and low training. Acemoglu, 1996, Redding, 1996, and Acemoglu and Pischke, 1998, also present models with multiple equilibria where under-provision of training is one of the possible equilibria.

The presence of network externalities does not necessarily produce multiple equilibria. In their model of local labor markets, Brunello and De Paola, 2004 show that a firm employing a new worker increases economic density in the local labor market and the expected profit that other firms can gain from training. However, higher density also reduces local unemployment and increases wages. 
Therefore, a side effect of higher density is that the vacancy - employment rate increases, which increases turnover and has a negative impact on training.

\section{The under - provision of training: empirical evidence}

The empirical literature on training suffers of measurement problems that hinder the achievement of ultimate conclusions. Training incidence and duration is usually measured using data drawn from household and employer surveys and from administrative data of single firms. These data contain self-reported training measures, which are affected by measurement errors because respondents may not exactly remember all their relevant training experiences, especially when the span of time between the training spell and the interview is long. Moreover, workers and firms may have different perceptions of training investments. As argued by Black e Lynch, 1995, p. 17, “...a supervisor who is assigned to work side-by-side with a new employee may view the time she spends with a new hire as training, whereas the employee views the fact that the supervisor is always hanging around as monitoring, not training". Barron et al.,1997b, using data from a matched employer-employee survey, find that the correlation between worker and establishment measures are lower than 0.5 and that establishments report on average 25 percent more hours of training than workers do.

These problems and the fact that informal training is rarely recorded in any survey makes it difficult to test human capital theory - as well as any other theory - of training. As far as the under - provision of training is concerned, an additional complication is that training costs and returns - on which efficiency evaluations are based - are very difficult to measure. On the one hand, individual productivity is hardly ever measured and the wage, which should approximate productivity, varies with many other factors, including labor market competition. On the other hand, respondents to surveys are unlikely to know the opportunity cost of training. When training is financed by the firm and the respondents are workers, it is also difficult to assess the direct money cost of training. 
According to some authors, the under-investment argument finds support in the combination of high private rates of return to training and low training incidence. Studies by Booth and Bryan, 2002, Frazis and Loewenstein, 1999, Aralampalam, Booth and Elias, 1997, Mincer, 1996, Blanchflower and Lynch, 1994, suggest that private rates of return to training are considerably higher than the real rate of return of corporate bonds - 4 percent - and to schooling - about 5-10 percent (Bishop, 1996). Frazis and Lowenstein find that 40 hours of training increase the wages of persons with low levels of tenure and experience by 8 percent, as much as a single year of education. Carneiro and Heckman, 2003, report that the return to private sector training in the US ranges between 16 and 26 percent. Evidence that the private returns to training are disproportionately high relative to other investments with similar risk suggests that there is some market failure, which prevents individuals from implementing their privately optimal plans. According to Lengermann, 1996, since workers generally do not experience reductions in wage rates or hours worked while they received company training, their private rate of return to training tends to be infinite. This might explain the large numbers of American, Canadian, Dutch and Swedish workers reporting that they are unable to get all the training they would like (Loewenstein and Spletzer, 1999).

The association of high returns to market failures, however, is problematic. Assuming that the marginal returns to training decrease with the stock invested, high observed returns are consistent both with the presence of liquidity constraints, which keep some individuals from investing, and with high marginal costs of training. While the former explanation supports under-provision, the latter explanation is perfectly in line with efficient provision.

In the case of imperfect labor markets, with firms bearing part or all the costs of training, evidence for under-investment may be gathered by looking at separation rates after training. As shown by equations [4] and [5], a positive value of $B$ - which measures the share of the productivity gain appropriated by the employee -reduces the investment by the firm and increases the investment by the employee, with a negative overall effect on training. The intuition for the 
negative effect is that, while the employee can capture her share of the returns to training in the labor market, the employer who invests can only capture her share with probability (1-q). Hence, the essential reason for under-provision is not that $B$ is positive, but that the turnover rate is different from zero, which creates a poaching externality.

Therefore, a preliminary step in the investigation of the under-investment problem is to clarify the competitive structure of the labor market. There is substantial evidence that the costs of training are financed by the employer, which can be read as an indicator of monopsony power (Barron, Berger and Black, 1999; Booth and Bryan, 2002; Loewenstein and Spletzer, 1998; Stevens, 1999). The willingness of firms to bear training costs could be due, however, to the firm - specific nature of the investment rather than to market power. The available empirical evidence suggests that skills provided by (formal) on-the-job training are seldom purely firm-specific (Neal 1995, Stevens 1994, 1999, Loewenstein and Spletzer, 1999), which points again to labor market imperfections. As documented by Bishop, 1997, a growing number of firms are training their workers in completely general skills such as mathematics, reading, writing, problem solving and interpersonal skills. Similarly, OECD, 2003a, reports that courses occurring outside the workplace impart essentially general skills.

The fact that firms formally pay for training does not imply that workers do not bear part of the cost through lower wages. When workers invest, we should observe a positive relationship between wage premia and training. A number of papers, investigating the relationship between training and wage compression, do not support this claim (Brunello, 2004; Ericson, 2004; Beckman, 2004; AlmeidaSantos and Mumford, 2003; Croce and Ghignoni 2004). Bassanini and Brunello, 2004, use data from the European Community Household Panel and measure the training wage premium - for different sub-groups of the employed population - as the differential between the median wage growth of trained and untrained 
employees. Their evidence clearly suggests a positive and statistically significant relationship between general training and wage compression. ${ }^{5}$

Moreover, empirical work using methods that control for the self - selection of individuals to treatment leads to positive but low estimated returns for training; see Bassanini, 2004, for the OECD, Pischke, 2000, for Germany, and Goux and Maurin, 1998, for France. Training returns not significantly different from zero are found by Leuven and Oosterbeek, 2002, who estimate the wage returns to workrelated training by restricting the group of untreated individuals to those who were willing to receive training in the Netherlands, but did not do so due to some random event.

In case of firms paying for general training, under-provision can occur because of involuntary or voluntary turnover. To investigate this aspect we use the 7 waves (1995-2001) of the European Community Household Panel (ECHP) for 12 European countries. The ECHP is a longitudinal survey modeled on the US Panel Study of Income Dynamics (PSID). This survey provides a wealth of information on individual income and socio-economic characteristics for all EU countries and aims to be representative both in cross-sections and longitudinally. Due to the common questionnaire, the information contained in the ECHP is, in principle, comparable across countries, which is its main strength. The data collection for the ECHP is made at the national level by National Data Collection Units (NDUs), with Eurostat providing centralized support and coordination.

The main question on vocational training in the ECHP is as follows "Have you at any time since January (year before the survey year) been in any vocational education or training, including part-time and short-courses?". From this question, we construct a dichotomous variable "training participation", which takes value 1 if the individual responded "yes" and 0 if she responded "no". Conditional on a positive answer, the individual is asked to report whether the received training was paid for or organized by the employer. We consider only individuals aged between 17 and 65 .

\footnotetext{
${ }^{5}$ The use of instrumental variables implies that findings by Bassanini and Brunello (2004) can be interpreted as evidence of a true casual relationship between wage premia and training.
} 
The ECHP dataset includes also two interesting questions on turnover behavior: first, workers are asked to indicate the year they stopped working in their previous job. Second, they are asked to indicate the reason of separation, which includes obtaining a more suitable job. We select the individuals who in the 1995 wave indicated that they had received employer provided training from January 1994 to the time of the survey and follow them in the next waves to find out whether they quitted their last job. To avoid obvious endogeneity problems, we only consider separations taking place in 1996 or later and compute both the percentage of trained individuals who separated in 1996 and the percentage that separated from 1996 to 2001 . Moreover, we distinguish between all separations, whatever the reason, and separations motivated by better economic conditions. Table 1 shows the results by country. We find that the separation rate is particularly high in Denmark and the UK, and low in Italy and Spain. Figure 1 illustrates the relationship between training and separations and suggests a positive correlation between these variables. We further investigate this issue by estimating for the sample of 11 countries a probit model of the probability of separation between year $\mathrm{t}+1$ and $\mathrm{t}+\mathrm{s}$ as a function of standard covariates and of a dummy indicating whether the individual has received employer - provided training from year $\mathrm{t}-1$ to year $\mathrm{t}$. When we allow $\mathrm{s}$ to be higher than 1 and look at separations taking place over an extended period of time, there is evidence (see Table 3 ) that having received employer-provided training significantly increases the probability of separation, especially if it is to a more suitable job.

The pooled estimates in Table 2 do not reveal the cross-country heterogeneity in the relationship between training and separation. As shown by Table 4, where we only report the estimated coefficient of the training dummy from country specific regressions, there is evidence of a statistically significant and positive relationship between employer - provided training and subsequent turnover for Denmark, Belgium, France and the UK. In the remaining countries the relationship is either not statistically significant or negative and statistically significant, as in the case of Finland. 
The evidence that in no country, except Finland, training significantly decreases the quit rate is suggestive of under-provision. ${ }^{6}$ However, we admit that the underlying assumption that firms pay for training requires further investigation.

Indirect evidence about the negative effects of turnover on training is provided by Brunello and Gambarotto, 2004 and Brunello and De Paola, 2004, who investigate how spatial agglomeration affects employer - provided training in the local labor markets of the UK and Italy. Dense labor markets, with more workers and more firms, present better opportunities to locate a better job than sparse labor markets, and are characterized by a higher risk of poaching. Local density, however, presents also advantages for training firms, because it generates positive knowledge spillovers. Brunello and Gambarotto use the UK data from the European Community Household Panel for the period 1994-2000 and show that employer-provided training is less frequent in economically denser areas. Their result is confirmed by Brunello and De Paola, who use data from a sample of Italian manufacturing firms.

\subsection{The influence of labor market institutions}

As discussed in Section 1, when firms have some monopsonistic power a number of new factors need to be considered for the evaluation of training investments. A large empirical literature has been devoted to test the influence of labor market institutions, such as the presence of unions and of wage bargaining, minimum wages and employment protection, on training provision (Grossberg and Sicilian, 1999; Neumark and Wascher, 2000; Acemoglu e Pischke, 2003; Arulampalam, Booth and Bryan, 2002; Bassanini and Brunello, 2004). As discussed below, the results of this research are not clear-cut.

Starting from the effect of minimum wages on training, the available empirical evidence is rather inconclusive, with recent studies on the United States and the

\footnotetext{
6 Different conclusions are obtained by Parent (1999), who, using a proportional hazard model, reports a negative effect of training with the current employer on separations in US. However, since the author controls for fixed effects without controlling for match specific effects, these results do not seem conclusive.
} 
United Kingdom reporting contradictory findings. We recall that in case of perfect labor market competition, according to the Beckerian theory the introduction of a minimum wage reduces training since some workers will not be able to finance training by accepting lower wages. On the contrary, when labor markets are characterized by monopsonistic power, minimum wages may increase training for low paid workers (Acemoglu and Pischke, 1999; Stevens, !994).

Early research by Mincer and Leighton, 1981, and Hashimoto, 1982, found that age-earnings profiles were significantly flatter among workers whose wages were bound by the minimum wage, which was interpreted as suggesting that an increase in the minimum wage significantly reduces on-the-job training. Sharply in contrast, Lazear and Miller, 1981, did not find a statistically significant relationship between the slope of age-earnings profiles and an indicator of whether the minimum wage was binding or not. However, more recent research by Grossberg and Sicilian, 1999, has shown that the effect of minimum wages on wage growth could be unrelated to the effect produced on training. As suggested by Acemoglu and Pischke, 1999, minimum wages eliminate the lower tail of the wage distribution and by so doing flatten the slope of the age-earning profile. This effect is independent of the impact of minimum wages on training. Leighton and Mincer, 1981, and Neumark and Wascher, 2001, using data on individual workers, consider the relationship between the variation of minimum wages across US states and the investment in training and find that the more binding is the minimum wage, the less likely is a worker to receive on-the-job training. Since the minimum wage variable used by Neumark and Wascher is at a higher level of aggregation than training, the estimated standard errors may understate the inaccuracy of the estimates. This problem is taken into account by Acemoglu and Pischke, 1999, who, by focusing on workers affected by minimum wages changes, find no evidence that minimum wages reduce training. At a more descriptive level, this result is confirmed by inspection of Figure 2, where we plot for 11 European countries the average percentage of trained individuals over the years 1995-1996 against the Kaitz index in 1995, computed as the ratio of the 
minimum wage to the average wage ${ }^{7}$. Since training incidence can depend on the industrial composition of each country, we use in the figure the predicted probability of training from a probit regression, which controls for education, gender, industry, firm size and public sector effects. Schiller, 1994, and Grossberg and Sicilian, 1999, adopt indicators of whether minimum wages are binding or not that vary with the individual worker. These two studies find opposite results: Schiller produces evidence that minimum wages reduce training, but Grossberg and Sicilian do not. Their approach, however, may be biased because the omitted determinants of training can also be correlated with their indicator of whether minimum wages are binding. Arulampalam, Booth and Bryan, 2004, use two different treatment groups, workers stating that they were affected by minimum wages and workers with a wage in 1998 below the minimum. Their study of British Household Panel Survey data finds no evidence that the introduction of the minimum wage in Britain in 1999 has reduced the training of treated workers. If anything, there is evidence that training has increased. ${ }^{8}$

A few studies investigate the relationship between training incidence, union coverage in collective bargaining and union density, with mixed results. Barron et al., 1987, use data from a survey of US employers and find that the proportion of non-supervisory workers in the firm covered by collective bargaining has a significant negative effect on total training. Earlier work by Duncan and Stafford, 1980, and Mincer, 1983, produce similar results. On the contrary, Lynch, 1992, finds evidence of a positive effect of unions on training in the US National Longitudinal Survey of Youth (NLSY). Similarly, Kennedy et al., 1994, find that

\footnotetext{
7 Source: Nickell and Layard (1999).

8 These diverging results may depend on the fact that in countries where the minimum wage is high it might be difficult to find a control group which is not directly or indirectly affected by the minimum wage. Conversely, in countries where the minimum wage is particularly low, the incidence of training in the treatment group is likely to be extremely small, since training is relatively infrequent at the bottom of the wage distribution. For the purpose of welfare evaluation it is also important to notice that minimum wages, by reducing employment, may reduce learning by doing and therefore can have a negative effect on human capital accumulation. As shown by Baker, 2003, this negative effect is not compensated by higher investments in education.
} 
Australian firms where unions are actively involved in bargaining have significantly higher training incidence, in spite of the fact that union density does not have statistically significant effects. Green, 1993, shows that unions in Britain have significant positive effects on training in small firms but virtually no effect in large firms. A positive union effect has been found also by Booth 1991; Greenhalgh and Mavrotas 1992; Arulampalam and Booth, 1998; Green, Machin and Wilkinson 1999, Booth, Francesconi and Zoega, 2003.

At a more descriptive level, Figure 3 plots average predicted training incidence by country, computed as in Figure 2, against union density. We detect a positive relationship, which is driven however by two countries, Denmark and Finland, with their high unionization rates and training incidence. Finally, Figure 4 plots average predicted training incidence by country against the index of employment protection. The negative correlation between these two variables does not confirm the view that the presence of high firing costs should encourage firms and workers to invest in training. One possible explanation is that high employment protection increases the outside option of insiders and therefore raises wages and reduces profits. In these circumstances, firms may have lower incentives to train. A complementary explanation has been offered by Arulampalam, Booth and Bryan, 2004, who argue that, in economies where permanent workers have high levels of employment protection, temporary contracts can provide a mechanism enhancing labor market flexibility. Since fixed term contracts are short, firms and employees have fewer incentives to invest in training. The combination of high employment protection, which increases the outside option of insiders, and fixed term contracts, could generate less training in the aggregate.

\section{Policies}

Training plays an important role in the European strategy for higher employment and competitiveness, as documented in a number of European Council resolutions, including the Luxembourg and the Lisbon agreements. The 
design of policies aimed at reducing the under-provision of training requires that the causes of under-provision be identified. It is particularly important to understand whether the relatively low provision of training is due to the firm or to the employee. For instance, the implementation of policies, which aim at removing liquidity constraints, should be based on hard evidence that these constraints are important. In Section 2 we have reviewed evidence showing that firms provide and pay for training, both general and specific. We have also argued that the positive relationship between training and wage compression is evidence that labor markets are not perfectly competitive. At the same time, we are not aware of any convincing evidence that under-provision is due to the presence of liquidity constraints. In many countries capital markets are far from being perfect, but there is not enough evidence enabling us to argue that these imperfections have serious implication for training investment. ${ }^{9}$

When labor markets are imperfectly competitive, the supply of training by firms is higher than in perfect competition, because wage compression increases profits. On the other hand, the demand for training by employees is lower than in perfect competition, because the wage gain from training is lower. As argued by Stevens, 2000, the fall in demand outweighs the increase in supply, because the employer gains only if the employee stays on. Therefore, training is lower than in the first best allocation even in absence of liquidity constraints.

Policies, which aim at increasing the level of training above the market level, should be designed to affect either supply or demand, or both. In this review, we focus on supply policies, which directly affect firms but also have repercussions on the demand side. Broadly speaking, supply policies can affect employer provided training at the margin if they influence marginal benefits and marginal costs, as shown by equation [4] in Section 1 of this review. Therefore, we find it convenient to organize our discussion in two parts, by classifying training policies as policies targeted to marginal benefits and policies targeted at marginal costs.

\footnotetext{
9 The relevance of credit constraints seems week also for investments in education, see for example Carneiro and Heckman (2002).
} 
Clearly framework conditions play an important role in influencing both training investment by workers and firms and the effectiveness of policies aimed at encouraging this kind of investment. In previous section has been discussed the relevance of labour market institutions such as minimum wages, unions and employment protection legislation and other features that lead to imperfect labour markets. A first best approach would be that of implementing structural reforms that help to re-establishing perfect labour market competition. However, as noticed by OECD (2003a), these reforms do not concern primarily training and their evaluation cannot be done without considering all the relevant trade-offs.

\subsection{Policies targeted at marginal benefits}

The marginal benefits of training to the employer are influenced by the productivity of training, labor turnover, the degree of wage compression and the inter-temporal discounting rate. Therefore, policies, which aim at increasing returns, should try to influence these variables, both by affecting structural and framework conditions and by direct targeting.

Institutions regulating labor and product markets can affect the provision of training. For example, policies, which increase labor market flexibility and favor the diffusion of temporary contracts can reduce the incentive to train because, as discussed in Section 2, returns accrue to the parties for a shorter span of time (Arulampalam, Booth and Bryan, 2004). Training can instead be encouraged by policies, which enhance cooperation among firms, such as anti-head-hunting cartels (Wakita, 1998), or favor the development of social norms conducive to a compressed wage structure (Akerlof - Yellen, 1990) and to voluntary restraints of poaching behavior (Finegold and Soskice, 1998; Soskice, 1994, Lynch, 1994).

The complementarity between training, technological change and education suggests that higher investment in training can be obtained as a by-product of policies designed to encourage innovative activities and educational attainment. Localization policies can also affect training by favoring the development of positive pooling externalities and knowledge spillovers. These policies, however, 
may also encourage turnover, which has negative effects on the incentive to invest in training. Finally, macroeconomic policies, which reduce the rate of interest and/or reduce the degree of uncertainty in the stream of future revenues have also positive implications for training.

Policies targeted directly at affecting the benefits of training include payback clauses and apprenticeship contracts. Both influence the benefits of training by affecting labor market turnover. Starting from apprenticeships, these contracts combine training and employment in a way, which enables people entering an occupation to develop skills and competencies specific to a particular job or sector. A feature of apprentice contracts is that training is co-financed by firms and workers. The reason is that apprentices are paid less than their productivity for the duration of the contract, and receive a substantial wage increase upon completion of the specified training period. By so doing, the firm can recoup part of the cost of training. The design of the contract is such that the (certified) qualification is awarded only at the end of the apprenticeship spell, which discourages workers from leaving before expected. At the same time, the commitment to pay a higher wage after training to retained employees reduces opportunistic behavior on the firm side. Malcomson, Maw and McCormick, 2003, show that regulations, which increase the length of the apprenticeship contract, accompanied by a subsidy for completed spells, can help in reaching an efficient level of training. Needless to say, these schemes work if employees who leave the firm before the end of the contract suffer a cost ${ }^{10}$. The cost is higher when the qualification awarded at the end of the apprenticeship is highly valued in the labor market. Ceteris paribus, this requires an adequate system of certification of skills.

On the one hand, the formal certification of acquired skills can be used to induce trainees to contribute to the cost of investing in training, because of the higher returns they can reap in the labor market. On the other hand, certification reduces asymmetric information, increases turnover and discourages firms from investing. While the supply of training falls, the demand increases, with uncertain

10 Rules imposed by the medieval guilds against workers leaving before completion of the apprenticeship have served this scope. 
effects on overall provision. These rather pessimistic conclusions change, however, if we take into account that the effectiveness of training is strictly influenced by the active participation of recipients. Acemoglu and Pischke, 2000, show that certification, by guaranteeing workers a higher wage, induces them to provide a high level of effort in the skill acquisition process. This may explain why firms in countries like Germany contribute in a substantial way to the general training of their apprentices even in the presence of formal certifications, which increase the portability of acquired skills at the end of the training period.

Training agreements such as payback clauses also require certification and the monitoring of employer - provided training. These agreements are essentially devices, which encourage firms to undertake the costs associated to training programs and impose a penalty on workers who quit within a certain period. These schemes help in solving two kind of problems: first, they reduces the risk of poaching, since workers are induced to stay with the firm providing training; second, they allow workers to invest in training even if they are credit constrained, because the employer is willing to anticipate training costs.

Legal frameworks, which establish and permit pay-back clauses in individual contracts or collective agreements are present in many European countries. Their practical diffusion, however, is limited, perhaps because it is difficult to contract upon the contents of training. ${ }^{11}$ Policies aimed at improving accreditation systems, which can effectively signal learning outcomes to the labor market, would play an important role in encouraging individuals to pay or to share the cost of their own training. ${ }^{12}$

\subsection{Policies targeted at marginal costs}

Since training is an intangible activity, difficult to quantify and monitor, policies that subsidize private or public providers are affected by the opportunistic

\footnotetext{
${ }^{11}$ Moreover, the penalty imposed on the trainee in the event of exit needs to be neither too low, otherwise quits cannot be discouraged, nor too high, otherwise workers will not accept the training contract.

12 For a discussion of these kind of policies see OECD (2003a).
} 
behavior of the parties, with negative consequences on the quality of the investment. This problem is particularly serious when training is completely financed by an external agent, who has to motivate both the provider and the recipient to behave efficiently. Rather than full financing, co-financing schemes are both a better tool for the provision of adequate incentives to employees and training providers and a way to deal with scarce public resources. Co-financing implies that the government pays only part of the training cost, which is also born in part by the employer and the employee who invest.

In this sub-section we discuss levy/grant schemes, train or pay schemes and tax deductions. Levy/grant schemes combine a tax levied on all firms - normally on payroll - with grants awarded to training projects presented by some firms.

If the burden of the tax is entirely on employees, net wages fall to compensate for the tax. If in addition the subsidy received by successful firms reduces in the same proportion the share of the training costs borne by trainees, this policy has no impact on employers but affect the training decisions of employees, with some redistribution from employees not receiving training to employees receiving it (Stevens, 2001). This conclusion is rather strong and requires both that employers are able to shift the burden of the tax entirely on employees and that employees can entirely appropriate the advantages of the subsidies in terms of a lower training price. If the second condition does not hold, and the price of training paid by employees remains constant, this policy does reduce the marginal costs of training faced by the employers receiving grants, with positive effects on employer - provided training. A correct evaluation of the impact of a levy / grant policy therefore requires information on the responsiveness of wages and training prices to changes in payroll taxes and training grants.

If the purpose of the levy/grant scheme is to reduce the poaching externality, taxes should be levied on profits rather than on wages. The intuitive reason is that the externality is driven by the profits from poaching and that these profits are not reduced by payroll taxes if the burden is entirely shifted onto 
wages. The advantage of the tax on profits is that it affects the marginal decision between training and poaching by reducing the profits from poaching.

Levy/grant schemes are fairly widespread within the European Union, and details are provided by OECD, 2003. One issue is who decides on the grants, the government - as in Denmark - or the social parties - as in Spain and in Italy. In the second case the active role of unions can help monitoring training quality and the design of training curricula with an eye to the portability of skills (see Ok and Tergeist, 2003). In any case, since grants are awarded on a case by case system both high procedural costs and risk of abuses need to be considered. It is also important to notice that awarded grants typically involving the funding of a fixed percentage of training costs or total costs up to a certain ceiling, are similar respectively to tax deductions and train or pay schemes, which, as explained below, may produce deadweight losses.

An alternative to the combination of levies and grants is "train or pay" schemes, with levies payable only if the training investment falls below a legal minimum. France is a typical example, with the Loi du 16 juillet 1971, which introduced a minimum training expenditure and required firms to pay a levy equal to the difference between the minimum and actual investment (OECD, 1993). A typical criticism raised against this scheme is that it can produce deadweight losses. (Ziderman, 1990). This scheme can be decomposed into a tax on payroll and a subsidy on training such that the net tax is equal to zero when the minimum required amount is attained. If firms can shift the payroll tax onto workers, the employer's benefits from training are not affected but the training subsidy shifts the marginal training cost downwards, thereby encouraging the provision of training by firms. With full shifting, however, the net wage falls, which reduces the demand for training by employees: the overall effect depends on the relative shifts of demand and supply. With no shifting, the employer's marginal net benefits from training are reduced when training is above the minimum requirement, but employees are unaffected. Deadweight losses emerge also for firms that would have spent less than the legal minimum. In fact, this 
system by driving marginal costs to zero, overpays the increase in training it induces.

Compared to levy/grant policies, train or pay schemes imply that firms do not have to apply for grants in order to fund their training projects. Where bureaucratic costs are high and public procedures slow, this could be an important advantage (Geber, 1993). A potential minus is that firms could use training as a perquisite with cosmetic rather than substantial effects on skill development. Another minus is that training decisions are decentralized, with limited opportunities for coordination and the development of national or sectoral training policies.

An open question is whether levy rates should vary across sectors. Training costs vary among industries and there is no agreement on whether levy rates should reflect these differences. Even if they should, it is questionable whether a differentiated policy can be implemented when some of the costs are not verifiable. If efficiency were the issue, a sector specific policy would require that the government have information on the sector - specific efficient level of training.

The last policy option is tax deductions from turnover, which allow firms to deduct some or all training costs and thereby to reduce corporate taxes. Tax deductions can be higher than 100 percent of total expenses, as in the case of I taly of the Netherlands. As in the case of train or pay levies, this policy does not distinguish between marginal and infra-marginal costs, and is therefore open to the same criticism: some of the training is subsidized even though firms would have invested anyway. An additional problem is that deductions work only as long as there are positive profits. One way to get around this is to allow firms to carry forward these expenses to fiscal years where profits are positive - see the detailed description on OECD, 2003.

All these policies are motivated by under-provision, that is, by a level of training below the efficient level. A different issue is the equitable distribution of training opportunities. Since human capital is an important source of income and job satisfaction, an equitable allocation would require some redistribution in favor 
of groups of individuals who are less likely to be trained. The key question here is whether economic policy should try to correct outcomes - differences in training or to modify initial conditions, which produce efficiently different outcomes - for instance differences in educational attainment. While important, this issue is beyond the scope of the current review.

\section{Summary}

Training and education have become standard keywords in most policy proposals dealing with unemployment, competitiveness and growth. These proposals almost unanimously suggest that proper policies should be designed to foster more education and more training. Are these proposals well justified on economic grounds? The answer is positive if we have evidence that the labor market generates under-provision. It is also positive if the efficient distribution of training in the economy does not correspond to the distribution, which maximizes social welfare.

This paper has reviewed both the theoretical underpinnings and the empirical evidence in support of under-provision of training. While there is little if any evidence in support of under-provision because of liquidity constraints to the demand side of the market, there is evidence that employers provide and pay for general training, and that the provision of skills encourages labor turnover. The combination of these two facts suggests that the labor market provides less training than optimal.

The balance of the existing empirical evidence suggests that policy discussions should focus on the employer rather than on employees. Therefore, we have concluded our review by discussing policies which affect the employer' marginal benefits and marginal costs of training. 


\section{Appendix}

If we allow for turnover to be affected by training investment, and let $q^{\prime}(s)$ be the marginal change of turnover induced by training, condition [4] becomes

$$
(1-q)\left\lfloor y^{\prime}(s)(1-\beta)\right\rfloor-(1-\beta) q^{\prime}(s) y(s)=(1-\sigma) c^{\prime}(s)
$$

We expect $q^{\prime}(s)$ to be positive when training is general and the accumulated skills are portable across jobs. On the other hand, $q^{\prime}(s)$ is likely to be negative when skills are firm - specific and can only be used productively in the training firm. In the former case, the marginal benefits of training decline, with negative effects on the investment. In the latter case they increase, with positive effects.

Assuming that the firm invests and bears all training costs, investment is efficient even in the presence of tumover if

$$
\left.\left.(1-q(s)) \mid y^{\prime}(s)-w^{\prime}(s)\right\rfloor-q^{\prime}(s)\right)[y(s)-w(s)]=y^{\prime}(s)
$$

which can be written as

$$
\left.q^{\prime}(s)\right)[y(s)(1-\beta)]=y^{\prime}(s)(q(s) \beta-\beta-q(s))
$$

so that the first best solution cannot be excluded a priori.

If firms cannot commit ex-ante to the wage they will pay to the trained worker and wages are set to maximize ex-post profits, a trade-off between high wages and low turnover rates emerges. In these circumstances, firms can use training as a commitment device to reduce turnover. Therefore, with ex-post wage determination, it is not possible to rule out training over-investment. This can be seen in equation [6].

The important point for this review, however, is that when the employer is involved in the provision of training - general or specific - part of the returns are appropriated by employees, which reduces the employer's incentive to invest. 
Even if employees invest more as a consequence, we expect overall investment to be below the first best, because of the poaching externality associated to labor turnover.

Table 1. Percentage of individuals who received employer provided training in 1995 and separated in years 1996 to 2001

\begin{tabular}{|l|c|c|c|c|}
\hline & $(1)$ & $(2)$ & $(3)$ & $(4)$ \\
\hline Denmark & 30.11 & 10.98 & 17.38 & 5.06 \\
\hline Belgium & 20.33 & 4.97 & 12.51 & 2.10 \\
\hline France & 15.64 & 3.79 & 8.72 & 1.95 \\
\hline UK & 34.04 & 13.88 & 19.57 & 7.36 \\
\hline \hline Ireland & 17.66 & 7.40 & 10.47 & 4.55 \\
\hline \hline Italy & 10.53 & 2.97 & 4.97 & 0.45 \\
\hline Greece & 16.32 & 6.28 & 6.72 & 1.10 \\
\hline Spain & 12.45 & 3.76 & 6.66 & 0.39 \\
\hline Portugal & 18.89 & 11.75 & 9.64 & 3.54 \\
\hline Austria & 21.27 & 7.68 & 10.99 & 2.52 \\
\hline \hline
\end{tabular}

Column 1: all separations between 1996 and 2001; Column 2: all separations in 1996; Column (3): separations to a better paying job between 1996 and 2001; Column (4): separations to a better paying job in 1996. Finland missing because ECHP starts for this country in 1996. 

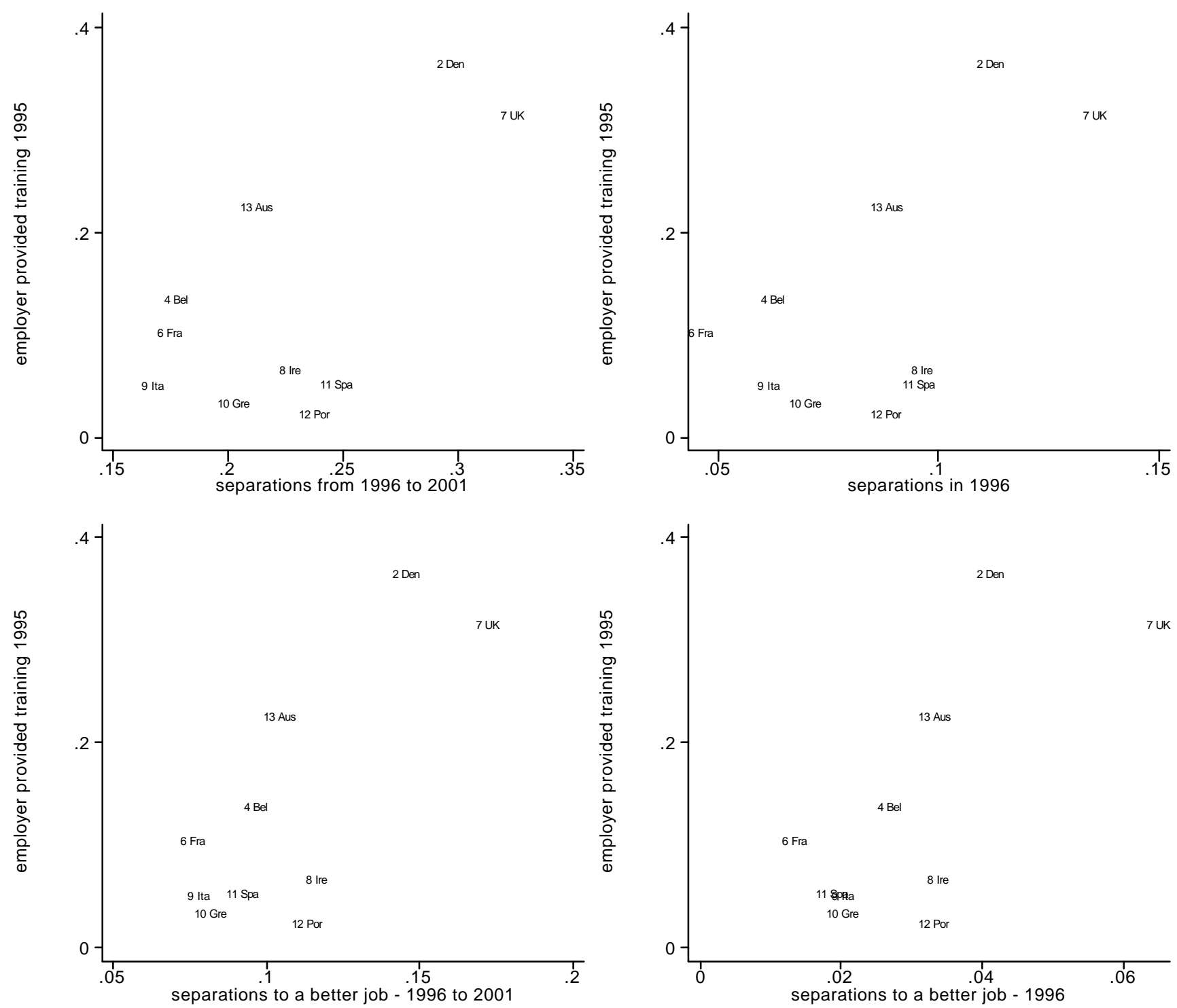

Figure 1. Employer provided training in 1995 and separations from 1996 onwards. Source: ECHP. 
Table 2. Probit estimates of the probability of separation in years $t+1$ to $t+s$ as a function of employer provided training in year $\mathrm{t}$

\begin{tabular}{|c|c|c|c|c|}
\hline \# obs : & $\begin{array}{l}154154 \\
(1)\end{array}$ & $\begin{array}{c}154154 \\
(2)\end{array}$ & $\begin{array}{c}154154 \\
(3)\end{array}$ & $\begin{array}{c}154154 \\
(4)\end{array}$ \\
\hline College & $\begin{array}{c}0.0584 \text { * } \\
(0.0143)\end{array}$ & $\begin{array}{l}-0.0127 \\
(0.0119)\end{array}$ & $\begin{array}{c}0.0684 \text { * } \\
(0.0185)\end{array}$ & $\begin{array}{l}-0.0192 \\
(0.0144)\end{array}$ \\
\hline Married & $\begin{array}{c}0.0724 \text { * } \\
(0.0119)\end{array}$ & $\begin{array}{c}0.0729 * \\
(0.0097)\end{array}$ & $\begin{array}{c}0.0237 \\
(0.0154)\end{array}$ & $\begin{array}{c}0.0241 \sim \\
(0.0116)\end{array}$ \\
\hline gender & $\begin{array}{c}0.1485 * \\
(0.0117)\end{array}$ & $\begin{array}{c}0.0646 * \\
(0.0095)\end{array}$ & $\begin{array}{c}0.1173 * \\
(0.0151)\end{array}$ & $\begin{array}{c}0.0443 * \\
(0.0114)\end{array}$ \\
\hline age & $\begin{array}{c}0.0013 \\
(0.0036)\end{array}$ & $\begin{array}{l}-0.0020 \\
(0.0027)\end{array}$ & $\begin{array}{c}0.0034 \\
(0.0047)\end{array}$ & $\begin{array}{l}-0.0011 \\
(0.0032)\end{array}$ \\
\hline Age squared & $\begin{array}{l}-0.0002 * \\
(0.0000)\end{array}$ & $\begin{array}{l}-0.0001 * \\
(0.0000)\end{array}$ & $\begin{array}{l}-0.0002 * \\
(0.0001)\end{array}$ & $\begin{array}{l}-0.0001 \\
(0.0000)\end{array}$ \\
\hline tenure & $\begin{array}{l}-0.0265 \star \\
(0.0039)\end{array}$ & $\begin{array}{l}-0.0811 \star \\
(0.0030)\end{array}$ & $\begin{array}{l}-0.0363 * \\
(0.0050)\end{array}$ & $\begin{array}{l}-0.0948 * \\
(0.0036)\end{array}$ \\
\hline Tenure squared & $\begin{array}{l}-0.0012 * \\
(0.0003)\end{array}$ & $\begin{array}{l}0.0020 * \\
(0.0002)\end{array}$ & $\begin{array}{l}-0.0004 \\
(0.0004)\end{array}$ & $\begin{array}{l}0.0029 * \\
(0.0003)\end{array}$ \\
\hline Job satisfaction & $\begin{array}{c}-0.0706 * \\
(0.0042)\end{array}$ & $\begin{array}{c}-0.0884 * \\
(0.0035)\end{array}$ & $\begin{array}{c}-0.0741 \star \\
(0.0054)\end{array}$ & $\begin{array}{l}-0.0934^{\star} \\
(0.0041)\end{array}$ \\
\hline Private sector & $\begin{array}{c}0.1982 * \\
(0.0203)\end{array}$ & $\begin{array}{c}0.1119 * \\
(0.0160)\end{array}$ & $\begin{array}{c}0.1771 * \\
(0.0263)\end{array}$ & $\begin{array}{c}0.0605^{\star} \\
(0.0190)\end{array}$ \\
\hline Monthly wage & $\begin{array}{c}0.0008 \\
(0.0008)\end{array}$ & $\begin{array}{c}0.0002 \\
(0.0007)\end{array}$ & $\begin{array}{c}0.0006 \\
(0.0010)\end{array}$ & $\begin{array}{c}0.0009 \\
(0.0007)\end{array}$ \\
\hline Training & $\begin{array}{c}0.0833 * \\
(0.0153)\end{array}$ & $\begin{array}{c}0.0225 \\
(0.0129)\end{array}$ & $\begin{array}{c}0.0576 * \\
(0.0199)\end{array}$ & $\begin{array}{l}-0.0118 \\
(0.0158)\end{array}$ \\
\hline$R-s q$ & 0.082 & 0.097 & 0.052 & 0.064 \\
\hline
\end{tabular}

Note: standard errors in parentheses with $\mathrm{p}<0.05=\sim, \mathrm{p}<0.01=*$. Column 1: separations to a better paying job between 1996 and 2001; Column 2: separations to a better paying job in 1996; Column (3): all separations between 1996 and 2001; Column (4): all separations in 1996. Germany excluded. 
Table 3. Probit estimates of the probability of separation in years $t+1$ to $t+s$ as a function of employer provided training in year $t$. By country

\begin{tabular}{|l|c|}
\hline & $\begin{array}{c}\text { Estimated coefficient of } \\
\text { the training dummy }\end{array}$ \\
\hline Denmark & $0.073^{\wedge}(0.037)$ \\
\hline Belgium & $0.266^{* *}(0.070)$ \\
\hline \hline France & $0.199 * *(0.072)$ \\
\hline UK & $0.079 * *(0.030)$ \\
\hline \hline Ireland & $-0.073(0.068)$ \\
\hline \hline Italy & $0.053(0.071)$ \\
\hline Greece & $0.000(0.127)$ \\
\hline Spain & $-0.073(0.064)$ \\
\hline Finland & $-0.166(0.138)$ \\
\hline Austria & $0.033(0.047)$ \\
\hline
\end{tabular}

Note: the covariates in these regressions are the same used in Table 3. ^: statistically significant at the 10 percent level; *: statistically significant at the 5 percent level; **: statistically significant at the 1 percent level; 


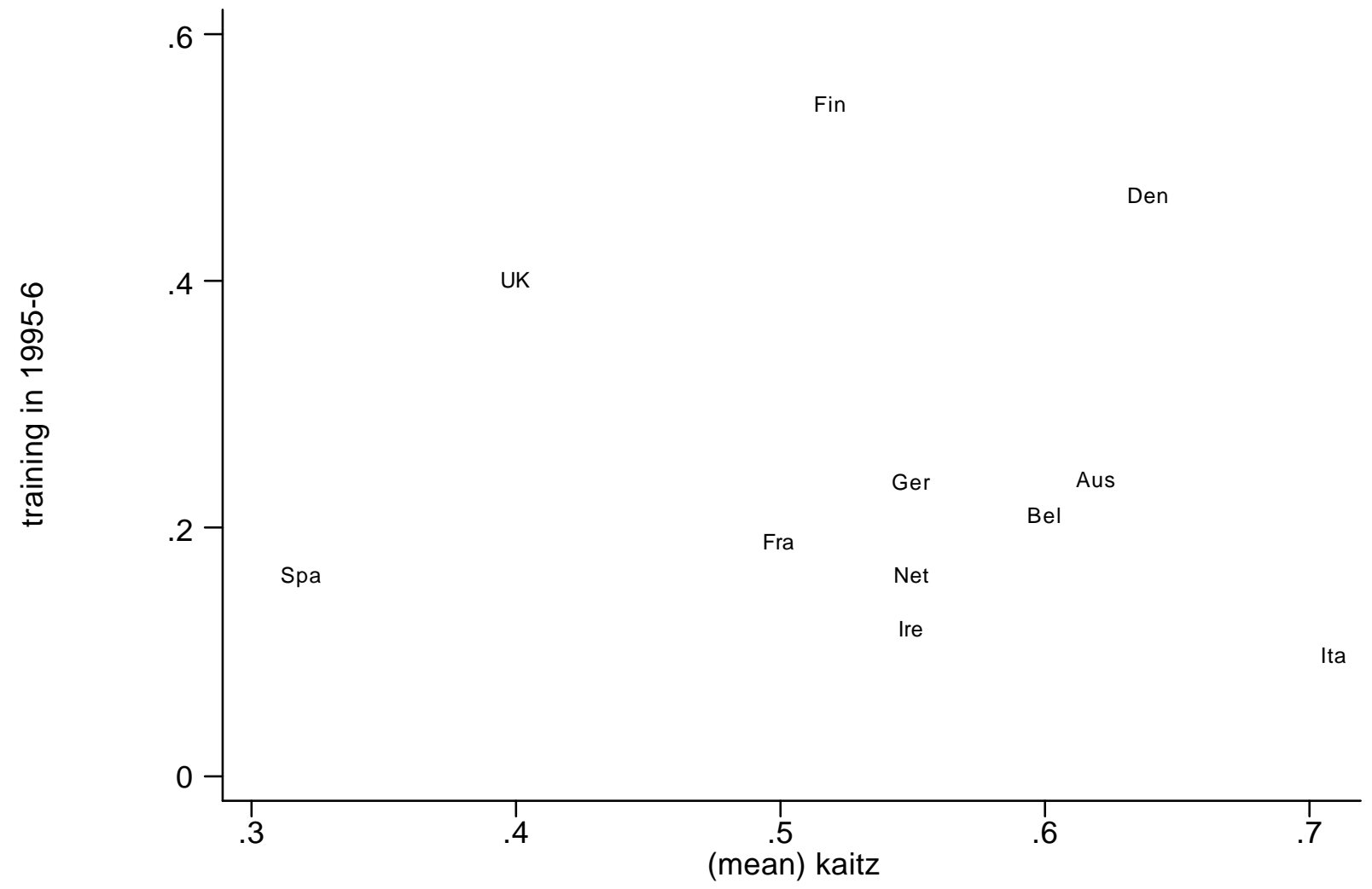

Figure 2. Average training incidence and the Kaitz index. Sources: ECHP and Nickell-Layard (1999) 


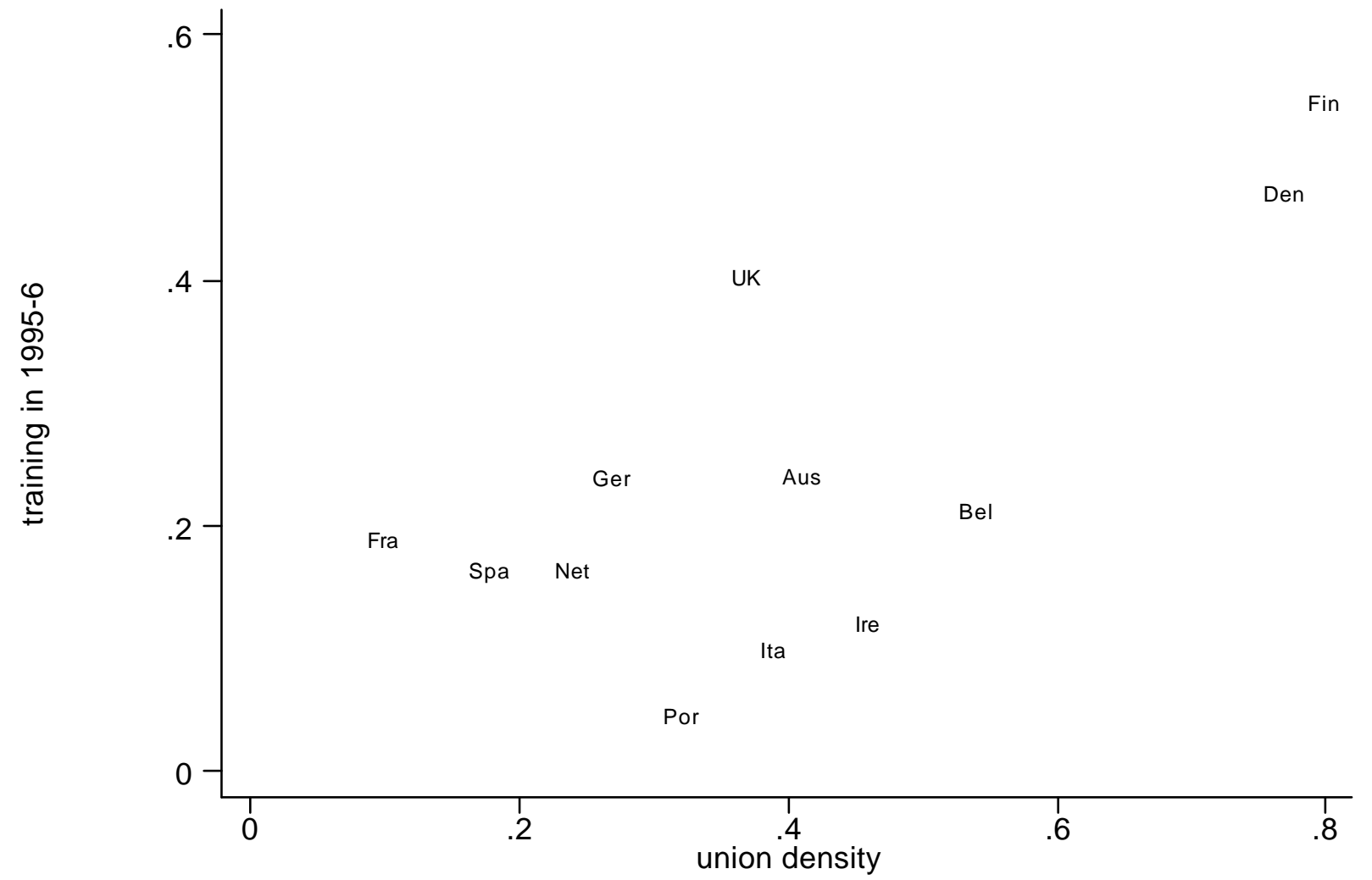

Figure 3. Average training incidence and union density. Sources: ECHP and Nickell-Layard (1999) 


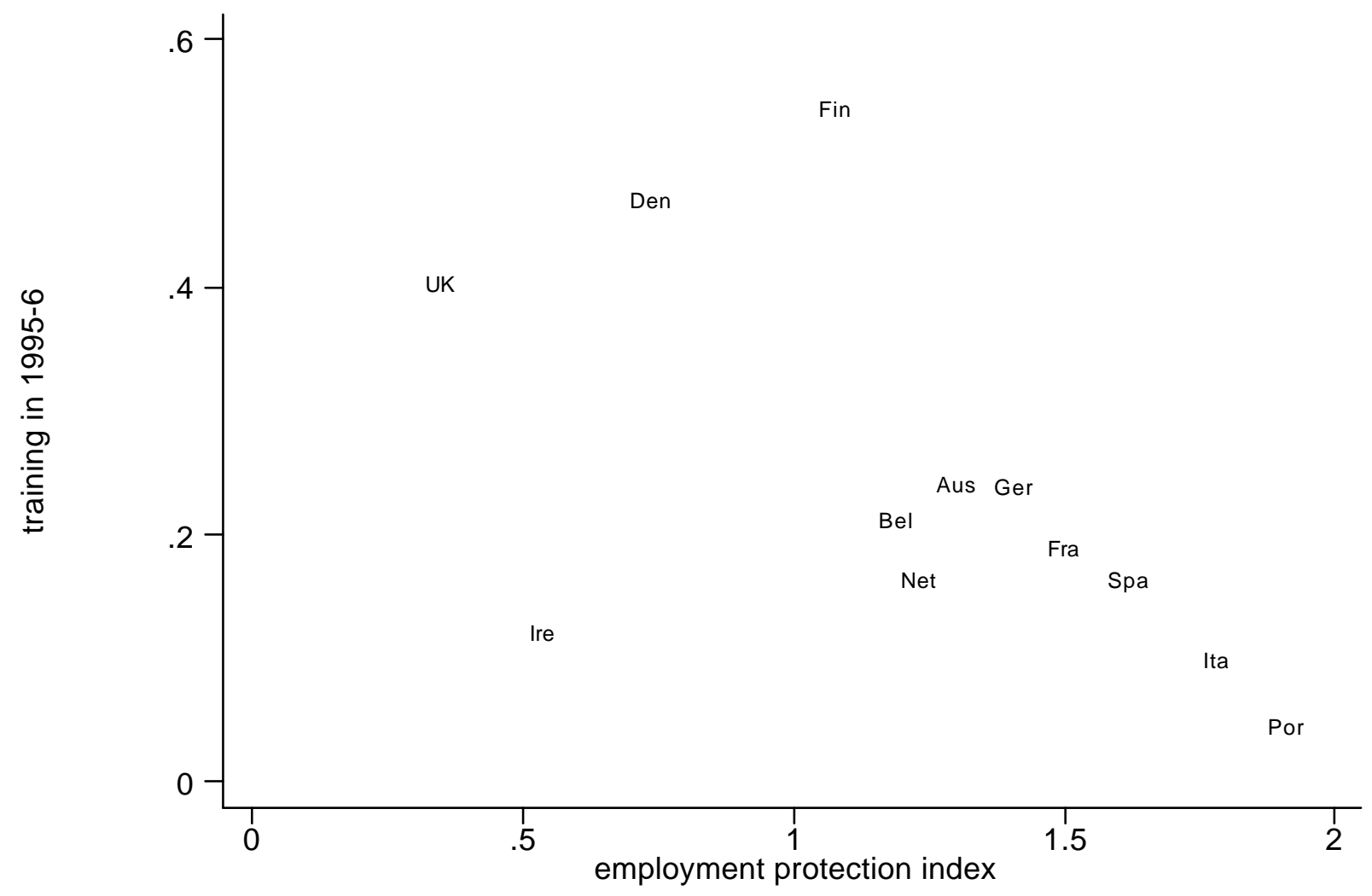

Figure 4. Average training incidence and employment protection. Sources: ECHP and Nickell-Layard (1999) 


\section{References}

Akerlof, G. and Yellen, J. (1990), The Fair Wage-Effort Hypothesis and Unemployment, Quarterly Journal of Economics 105, pp. 255 - 283.

Autor, D. (2004), Why Do Temporary Help Firms Provide Free General Skills?, Quarterly Journal of Economics, , Forthcoming.

Acemoglu, D. (1996), Microfoundation For Social Increasing Returns in Human Capital Accumulation, Quarterly Journal of Economics, 111, pp. 779-804.

Acemoglu, D. (1997), Training and Innovation in an Imperfect Labor Market, Review of Economic Studies, 64, pp. 445-464.

Acemoglu, D. and Pischke, J. (1998), Why do Firms Train? Theory and evidence, Quarterly Journal of Economics, 113, pp. 79-119.

Acemoglu, D. and Pischke, J. (1999b). The Structure of Wages and Investment in General Training, J ournal of Political Economy, pp. 539-72.

Acemoglu, D. and Pischke, J. (1999a), Beyond Becker: Training in Imperfect Labor Market, Economic J ournal, 109 (February), F112-F142.

Acemoglu, D. and Pischke, J. (2000), Certification of Training and Training Outcomes, European Economic Review, 44, 917-927.

Acemoglu, D. and J.-S. Pischke (2003), Minimum Wage and On-the-Job Training, Research in Labor Economics, forthcoming.

Acemoglu, D. (1997), Training and Innovation in an Imperfect Labor Market, Review of Economic Studies, 64, pp. 445-64.

Almeida-Santos, F. and Mumford, K. (2003), Employee Training, Wage Compression and Workplace Performance in Britain, mimeo.

Ariga, K., Brunello, G. (2002), Investment in Human Capital and Promotions in a Corporate Hierarchy, IZA working, n.577.

Arulampalam, W. and Booth A. (1998), Labour Market Flexibility and Skills Acquisition: Is There a Trade-off?, British J ournal of Industrial Relations, 36, 4, pp. 521-536.

Arulampalam, W., Booth A. and Elias, P. (1997), Work-Related Training and Earnings Growth for Young Men in Britain, in Polachek, S., (ed.), Research in labor economics, Vol. 16, 119-47, Greenwich, Conn. and London: JAl Press.

Arulampalam, W., Booth A. and Bryan M. (2004), Training and the new minimum wage, Economic Journal, 114, 494, C87.

Baker, M. (2003), Minimum Wages and Human Capital Investments of Young Workers: Work Related Training and School Enrolment, mimeo, University of Toronto.

Barron, J. M., Berger M. and Black D. (1997), On-the-Job Training, W.E Upjohn Institute for Employment Research.

Barron, J. M., Berger, M. and Black, D. (1999), Do Workers Pay for On-the-Job Training?, J ournal of Human Resources 34, 2 , pp. 236-252.

Barron, J. M., Black, D. and Loewenstein, M. (1989), Job Matching and On-the-job Training, J ournal of Labor Economics, 7 (1), pp. 1-19.

Bassanini, A. and Brunello G. (2003), Is Training More Frequent when Wage Compression is Higher? Evidence from the European Community Household Panel, OECD, Paris, and University of Padua, mimeo.

Becker, G. (1962), Investment in Human capital: a Theoretical Analysis, Journal of Political Economy, 70, pp 9-49

Becker, G. (1964), Human Capital, The University of Chicago Press, Chicago. 
Beckmann M. (2004), Wage Compression and Firm-sponsored Training in Germany: Empirical Evidence for the Acemoglu-Pischke Model from a Zero-inflated Count Data Model, mimeo.

Bhaskar, V. and Holden, S. (2003), Wage Differentiation via Subsidised General Training, CESifo Working Paper Series, No. 848.

Bishop, J. (1994), The Impact of Previous Training on Pro-ductivity and Wages, in L. Lynch (ed.),Training and the Private Sector: International Comparisons, Chicago: University of Chicago Press, 1994).

Bishop, J. (1997), What We Know about Employer-Provided Training: A Review of the Literature, in Polachek, e Solomon, W., eds., Research in Labor Economics. London, J Al Press, pp. 19-87

Blanchflower, D. and Lynch, L. (1994), Training at Work: A Comparison of U.S. and British Youths, in Lynch, L. (ed.), Training and the private sector: International comparisons, National Bureau of Economic Research, Comparative Labor Markets Series, Chicago and London: University of Chicago Press, 233-60.

Blau, F. and Kahn, L. (1983), Job Search and Unionized Employment, Economic Inquiry, 21 (3), pp. 412-30.

Booth, A. (1991), J ob-related Formal Training: Who Receives It And What Is It Worth?, Oxford Bulletin of Economics and Statistics, 53, pp. 281-294.

Booth, A. (1993), Private Sector Training and Graduate Earnings, Review of Economics and Statistics, 76, pp. 164-70.

Booth, A. and Chatterji M. (1998), Unions and Efficient Training, The Economic Journal, 108, 447, pp. 328-343

Booth, A. and Bryan M. (2002), Who Pays for General Training? New evidence for British Men and Women, IZA Discussion Paper No. 486, April.

Booth, A., Francesconi, M., and Zoega G. (1999), Training, Rent-sharing and Unions, CEPR Discussion Paper Series, No. 2200.

Booth A. and Zoega G. (2000), Why do Firms Invest in General Training? 'Good' Firms and 'Bad' Firms as a Source of Monopsony Power, Institute for Labour Research, working papers n. 058, University of Essex.

Brunello, G. (2003), On the Complementarity between Education and Training in Europe, in Checchi and Lucifora, (eds.), Education, Training and Labour Market Outcomes in Europe, Palgrave, McMillan.

Brunello, G. and De Paola, M. (2004), Training and the density of economic activity: evidence from Italy, IZA working papers $\mathrm{n} .1173$.

Brunello, G. and Gambarotto, F. (2004), Agglomeration effects on employer - provided training: evidence from the UK, IZA Discussion Paper 1055.

Brunello, G. and Medio, A. (2001), An explanation of international differences in education and workplace training, Vol. 45, 2, pp. 307-322.

Carneiro P. and Heckman J. (2004), The Evidence on Credit Constraints in PostSecondary Schooling, Economic Journal, 112, pp.705-34.

Croce G. and Ghignoni E. (2004), Training by firms in Italian regional labour markets: the effects of education and unemployment, CRISS discussion paper $\mathrm{n} .6$

Heckman, J. and Carneiro, P. (2003), Human Capital Policy, NBER Working Papers 9495.

De la Fuente A. and A. Ciccone (2002), Human capital in a global and knowledge-based economy, European Commission. Employment and Social Affairs, May.

Dearden, L., Reed H. and Van Reenen J. (2000), "Who gains when workers train? Training and corporate productivity in a panel of British industries", Centre for Economic Policy Research Discussion, Paper No. 2486. 
De Paola M. and Scoppa V. (2003), The Firm's Moral Hazard in Training Provision, Politica Economica, XIX, n.1, Aprile 2003, pp. 31-61.

Duncan, G., and Stafford, F. (1980), Do Union Members Receive Compensating Differentials? American Economic Review, 70, pp. 355-371.

Ericson T. (2004), The Effects of Wage Compression on Training: Swedish Empirical Evidence, mimeo.

Fella, G. (2004), Termination restrictions and investment in general training, European Economic Review, forthcoming.

Finegold B. and Soskice, D. (1988), The Failure of Training in Britain: Analysis and Prescription, Oxford Review of Economic Policy, , pp. 21-51.

Frazis, H., and Loewenstein M. A. (1999), Reexamining the Returns to Training: Functional Form, Magnitude, and Interpretation, United States Bureau of Labor Statistics, Office of Employment Research and Program Development, Working paper 325.

Freeman, R. and Medoff, J. (1984), What Do Unions Do? , New York: Basic Books.

Green, F. (1993), The Determinants of Training of Male and Female Employees in Britain, Oxford Bulletin of Economics and Statistics, 55 (1), pp. 103-22. Blackwell Publishers.

Green, F., Machin, S. and Wilkinson D. (1999), Trade Unions and Training Practices in British Workplaces, Industrial and Labor Relations Review, 52, 2, pp. 179-195.

Greenhalgh, C. and Mavrotas G. (1994), The Role of Career Aspirations and Financial Constraints in Individual Access to Vocational Training, Oxford Economic Papers, 46, pp. 579-604.

Greenhalgh, C. and Stewart, M. (1987), The Effects and Determinants of Training, Oxford Bulletin of Economics and Statistics, 49 (2) pp. 171-90.

Grossberg A. and Sicilian P. (1999), Minimum wages, training and wage growth, Southern Economic Journal, 65, 539-556.

Hall, R. (1999), Reorganization, NBER Working Paper n. 7181

Harris, R. (1999), The Determinants of Work-Related Training in Britain in 1995 and the Implications of Employer Size, Applied Economics; 31, 4, April 1999, pages 451 63.

Hashimoto, M. (1981), Firm-Specific Human Capital as a Shared Investment, American Economic Review, 71, pp. 475-482.

Hashimoto, M. (1982), Minimum Wage Effects on Training on the Job, American Economic Review 72, pp. 1070-87.

Heckman, J. (2000), Policies to Foster Human Capital, Joint Center for Poverty Research Working Paper, n. 154, University of Chicago.

Henderson V, Kuncoro A. and Turner M. (1995), Industrial Development of Cities, Journal of Political Economy, 103, 1067-1090

Hersch, R. (1991), Education Match and Job Match, The Review of Economics and Statistics, 73, 1, pp. 140-44,

Jacobs, J., Lukens, M. e Useem, M. (1996), Organizational, Job, and Individual Determinants of Workplace Training: Evidence from the National Organizations Survey, Social Science Quarterly; 77,1, March, pages 159-76.

Jansen, M. (1998), Tenure, Training and Unemployment, mimeo.

Kahn, C., e Huberman, G. (1988), Two-sided Uncertainty and 'Up-or-Out' Contracts, J ournal of Labor Economics, 6, 423-44.

Katz, E. and Ziderman, A. (1990), Investment in General Training: The Role of Information and Labour Mobility, Economic Journal, vol. 100, pp. 1147-58. 
Kennedy, S., Drago, R., Sloan, J. and Wooden, M.(1994), The Effect of Trade Unions on the Proand Humanities Research Council of Canada. vision of Training: Australian Evidence, Journal of Industrial Relations, 32, 4, pp.565- 580.

Layard, R., Robinson, P. and Steedman, H. (1995), Lifelong learning, CEP occasional paper n.9.

Lazear, E. and Miller F. (1981), Minimum wage versus minimum compensation, in Report of the minimum wage study commission, 5. Washington, DC: U.S. Government Printing Office, pp. 347-80.

Lazear, E. and Miller F. (1981), Minimum Wages Versus Minimum Compensation, in Report of the Minimum Wage Study Commission, vol. 5, Washington, DC: US Government Printing Office.

Leighton, L. and Mincer J. (1981), The effects of minimum wages on human capital formation. In The economics of legal minimum wages, edited by Simon Rottenberg. Washington, DC: American Enterprise Institute, pp. 155-73.

Leighton, L. and Mincer J. (1981), The Effects of the Minimum Wage on Human Capital Formation, in Simon Rottenberg, (Ed.) The Economics of Legal Minimum Wages.. Washington, DC: American Enterprise Institute for Public Policy Research.

Lengermann, P. (1996), Training's Impact on Wages and Hours Worked: A Comparison of the Benefits and costs of Training, Economics of Education Review,

Leuven, E. (2004), The economics of private-sector training, Journal of Economic Surveys, forthcoming.

Leuven, E. and Oosterbeek H. (1999), The Demand and Supply of Work-Related Training: Evidence from Four Countries, Research in Labor Economics, 18, pp. 303330.

Loewenstein M. A and Spletzer J. (1998), Dividing the Costs and Returns to General Training, J ournal of Labor Economics, 16(1), pp.142-171..

Lowenstein, M., and Spletzer J. (1999), General and Specific Training: Evidence and Implications, Journal of Human Resources, 34(4), pp. 710-733.

Lynch, L. (1992), Private Sector Training and the Earnings of Young Workers, American Economic Review, vol. 82, pp. 299-312.

Lynch, L. (1994), editor, Training and the Private Sector: International Comparisons, Chicago: University of Chicago Press.

Lynch, L., and Black, S. (1995), Beyond the Incidence of Training: Evidence from a National Employers Survey, Working Paper No. 5231, National Bureau of Economic Research, Cambridge.

Malcomson, J., Maw, J., e McCormick B. (2002), General Training by Firms, Apprentice Contracts, and Public Policy, European Economic Review, Vol. 47, No. 1, pp. 197227.

MacLeod, B. and Malcomson, J. (1993), Specific Investments and Wage Profiles in Labour Markets, European Economic Review, 37, pp. 343-354.

Mclntosh, S. (1999), A Cross-Country Comparison of the Determinants of Vocational Training, Center for Economic Performance, Working Paper n. 432, London School of Economics, London.

Mincer J. (1962), On-the-J ob Training: Costs, returns and some implications, Journal of Political Economy.

Mincer, J. (1983), Union Effects: Wages, Turnover, and Job Training, Research in Labor Economics, Supplement 2, pp. 217-252.

Mincer J. (1996), Training: Costs, Returns, and Wage Profiles, The economics of training, Theory and measurement, in Ashenfelter, O., LaLonde, R.,(eds), Elgar 
Reference Collection, International Library of Critical Writings in Economics, vol. 65, 105-23, Cheltenham, U.K.

Moen, E. and Rosen, A (2002), Does Poaching Distort Training?, CEPR Discussion Paper No. 3468.

Neal, D. (1995), Industry-Specific Human Capital: Evidence from Displaced Workers, J ournal of Labor Economics, 13, 4, pp. 653-677.

Neumark, D. and Wascher W. (2001), Minimum Wages and Training Revisited, Journal of Labor Economics, Vol. 19, No. 3, pp. 563-595.

OECD (1999), Employment Outlook, Paris.

OECD (2001), The Economics and Finance of Lifelong Learning, Paris.

OECD (2003a), Upgrading Workers' Skills and Competencies, chapter 5, Employment Outlook, Paris.

OECD (2003b), Beyond Rhetoric: Adult Learning Policies and Practices, Paris.

OECD (2003c), Descriptions and Evaluations of Recent Experience with Mechanisms for Co-financing Lifelong Learning: Reports Prepared by National Authorities and Members of the ELAP Network, prepared for the "Second International Seminar: Mechanisms for the Co-finance of Lifelong Learning", London, 27-29 November, OECD, Paris.

Ok W. and Tergeist, P. (2003), Improving Workers' Skills: Analytical Evidence and the Role of the Social Partners, OECD Social, Employment and Migration Working Papers.

Olson, C. (1996), Who Receives Formal Firm Sponsored Training in the U.S.?, Working Paper No. 12, Institute of Industrial Relations. Berkeley: University of California.

Prendergast, C. (1993), The Role of Promotion in Inducing Specific Human Capital Acquisition, Quarterly Journal of Economics, 1993, 108, 523- 34.

Redding S. (1996), The Low-Skill, Low-Quality Trap: Strategic Complementarities between Human Capital and R\&D, The Economic J ournal, 106, pp. 458-70

Ryan, P. (1994), Training quality and trainee exploitation, in R. Layard, K. Mayhew and G. Owen (eds), Britain's Training Deficit, Aldershot: Avebury.

Rosen, S. 1976, A Theory of Life Earnings, Journal of Political Economy; 84,4, Part 2, Aug., pp. S45-67.

Sicherman, N. (1990), Overeducation, in the Labor Market, Journal of Labor Economics, 9, 2, pp.101-122

Simon I. and Kaestner R. (2003), Do minimum wages affect non-wage job attributes? Evidence on fringe benefits and working conditions, NBER Working Paper $n .9688$.

Schiller, B. (1994), Moving up: The training and wage gains of minimum-wage entrants. Social Science Quarterly, 75, 622-36.

Snower, D. (1996), The Low-Skill, Bad-Job Trap, 1996, in Acquiring Skills (ed. with Alison Booth), Cambridge: Cambridge University Press, pp.109-124.

Soskice, D. (1994), Reconciling Markets and Institutions: The German Apprenticeship System, in: L.M Lynch (ed.) Training and the Private Sector, International Comparisons, Chicago: University of Chicago Press, pp. 1-24.

Stevens, M. (1994), A Theoretical Model of On-the-Job Training with Imperfect Competition, Oxford Economic Papers, Vol. 46, No. 4, pp. 537-562.

Stevens, M. (1996), Transferable Training and Poaching Externalities, in A.L. Booth and D.J. Snower (eds.), Acquiring Skills: Market Failures, Their Symptoms and Policy Responses, Cambridge University Press, Cambridge, UK.

Stevens, M. (1999), Human Capital Theory and UK Vocational Training Policy, Oxford Review of Economic Policy, 15, 1, pp. 16-32. 
Stevens, M. (2001), Should firms be required to pay for vocational training?, Economic Journal,.111, pp. 485-505.

Veum, J.R. (1996), Gender and race differences in company training, Industrial Relations 35, pp. 32-44.

Wakita S. (1998), A Model for Patterns of Industrial Relations, in Ohashi I. e Tachibanaki T. (eds), Internal Labour Markets, Incentives and Employment, MacMillan Press, London.

Williamson, O. (1975), Markets and Hierarchies, New York: The Free Press.

Whalley, J. and Ziderman A. (1990), Financing Training in Developing Countries: The Role of Payroll Taxes, Economics of Education Review, 9, 4. 


\section{CESifo Working Paper Series}

(for full list see www.cesifo.de)

1225 Volker Grossmann, How to Promote R\&D-based Growth? Public Education Expenditure on Scientists and Engineers versus R\&D Subsidies, June 2004

1226 Bart Cockx and Jean Ries, The Exhaustion of Unemployment Benefits in Belgium. Does it Enhance the Probability of Employment?, June 2004

1227 Bertil Holmlund, Sickness Absence and Search Unemployment, June 2004

1228 Klaas J. Beniers and Robert Dur, Politicians' Motivation, Political Culture, and Electoral Competition, June 2004

1229 M. Hashem Pesaran, General Diagnostic Tests for Cross Section Dependence in Panels, July 2004

1230 Wladimir Raymond, Pierre Mohnen, Franz Palm, and Sybrand Schim van der Loeff, An Empirically-Based Taxonomy of Dutch Manufacturing: Innovation Policy Implications, July 2004

1231 Stefan Homburg, A New Approach to Optimal Commodity Taxation, July 2004

1232 Lorenzo Cappellari and Stephen P. Jenkins, Modelling Low Pay Transition Probabilities, Accounting for Panel Attrition, Non-Response, and Initial Conditions, July 2004

1233 Cheng Hsiao and M. Hashem Pesaran, Random Coefficient Panel Data Models, July 2004

1234 Frederick van der Ploeg, The Welfare State, Redistribution and the Economy, Reciprocal Altruism, Consumer Rivalry and Second Best, July 2004

1235 Thomas Fuchs and Ludger Woessmann, What Accounts for International Differences in Student Performance? A Re-Examination Using PISA Data, July 2004

1236 Pascalis Raimondos-Møller and Alan D. Woodland, Measuring Tax Efficiency: A Tax Optimality Index, July 2004

1237 M. Hashem Pesaran, Davide Pettenuzzo, and Allan Timmermann, Forecasting Time Series Subject to Multiple Structural Breaks, July 2004

1238 Panu Poutvaara and Andreas Wagener, The Invisible Hand Plays Dice: Eventualities in Religious Markets, July 2004

1239 Eckhard Janeba, Moral Federalism, July 2004 
1240 Robert S. Chirinko, Steven M. Fazzari, and Andrew P. Meyer, That Elusive Elasticity: A Long-Panel Approach to Estimating the Capital-Labor Substitution Elasticity, July 2004

1241 Hans Jarle Kind, Karen Helene Midelfart, Guttorm Schjelderup, Corporate Tax Systems, Multinational Enterprises, and Economic Integration, July 2004

1242 Vankatesh Bala and Ngo Van Long, International Trade and Cultural Diversity: A Model of Preference Selection, July 2004

1243 Wolfgang Eggert and Alfons J. Weichenrieder, On the Economics of Bottle Deposits, July 2004

1244 Sören Blomquist and Vidar Christiansen, Taxation and Heterogeneous Preferences, July 2004

1245 Rafael Lalive and Alois Stutzer, Approval of Equal Rights and Gender Differences in Well-Being, July 2004

1246 Paolo M. Panteghini, Wide vs. Narrow Tax Bases under Optimal Investment Timing, July 2004

1247 Marika Karanassou, Hector Sala, and Dennis J. Snower, Unemployment in the European Union: Institutions, Prices, and Growth, July 2004

1248 Engin Dalgic and Ngo Van Long, Corrupt Local Government as Resource Farmers: The Helping Hand and the Grabbing Hand, July 2004

1249 Francesco Giavazzi and Guido Tabellini, Economic and Political Liberalizations, July 2004

1250 Yin-Wong Cheung and Jude Yuen, An Output Perspective on a Northeast Asia Currency Union, August 2004

1251 Ralf Elsas, Frank Heinemann, and Marcel Tyrell, Multiple but Asymmetric Bank Financing: The Case of Relationship Lending, August 2004

1252 Steinar Holden, Wage Formation under Low Inflation, August 2004

1253 Ngo Van Long and Gerhard Sorger, Insecure Property Rights and Growth: The Roles of Appropriation Costs, Wealth Effects, and Heterogeneity, August 2004

1254 Klaus Wälde and Pia Weiß, International Competition, Slim Firms and Wage Inequality, August 2004

1255 Jeremy S. S. Edwards and Alfons J. Weichenrieder, How Weak is the Weakest-Link Principle? On the Measurement of Firm Owners' Control Rights, August 2004

1256 Guido Tabellini, The Role of the State in Economic Development, August 2004 
1257 François Larmande and Jean-Pierre Ponssard, EVA and the Controllability-congruence Trade-off: An Empirical Investigation, August 2004

1258 Vesa Kanniainen and Jenni Pääkkönen, Anonymous Money, Moral Sentiments and Welfare, August 2004

1259 Panu Poutvaara and Andreas Wagener, Why is the Public Sector More Labor-Intensive? A Distortionary Tax Argument, August 2004

1260 Lars P. Feld and Stefan Voigt, Making Judges Independent - Some Proposals Regarding the Judiciary, August 2004

1261 Joop Hartog, Hans van Ophem, and Simona Maria Bajdechi, How Risky is Investment in Human Capital?, August 2004

1262 Thomas Eichner and Rüdiger Pethig, Efficient Nonanthropocentric Nature Protection, August 2004

1263 David-Jan Jansen and Jakob de Haan, Look Who's Talking: ECB Communication during the First Years of EMU, August 2004

1264 David F. Bradford, The X Tax in the World Economy, August 2004

1265 Hans-Werner Sinn, Migration, Social Standards and Replacement Incomes. How to Protect Low-income Workers in the Industrialized Countries against the Forces of Globalization and Market Integration, August 2004

1266 Wolfgang Leininger, Fending off one Means Fending off all: Evolutionary Stability in Submodular Games, August 2004

1267 Antoine Bommier and Bertrand Villeneuve, Risk Aversion and the Value of Risk to Life, September 2004

1268 Harrie A. A. Verbon and Lex Meijdam, Too Many Migrants, Too Few Services: A Model of Decision-making on Immigration and Integration with Cultural Distance, September 2004

1269 Thomas Eichner and Rüdiger Pethig, Economic Land Use, Ecosystem Services and Microfounded Species Dynamics, September 2004

1270 Federico Revelli, Performance Rating and Yardstick Competition in Social Service Provision, September 2004

1271 Gerhard O. Orosel and Klaus G. Zauner, Vertical Product Differentiation When Quality is Unobservable to Buyers, September 2004

1272 Christoph Böhringer, Stefan Boeters, and Michael Feil, Taxation and Unemployment: An Applied General Equilibrium Approach, September 2004 
1273 Assaf Razin and Efraim Sadka, Welfare Migration: Is the Net Fiscal Burden a Good Measure of its Economics Impact on the Welfare of the Native-Born Population?, September 2004

1274 Tomer Blumkin and Volker Grossmann, Ideological Polarization, Sticky Information, and Policy Reforms, September 2004

1275 Katherine Baicker and Nora Gordon, The Effect of Mandated State Education Spending on Total Local Resources, September 2004

1276 Gabriel J. Felbermayr and Wilhelm Kohler, Exploring the Intensive and Extensive Margins of World Trade, September 2004

1277 John Burbidge, Katherine Cuff and John Leach, Capital Tax Competition with Heterogeneous Firms and Agglomeration Effects, September 2004

1278 Joern-Steffen Pischke, Labor Market Institutions, Wages and Investment, September 2004

1279 Josef Falkinger and Volker Grossmann, Institutions and Development: The Interaction between Trade Regime and Political System, September 2004

1280 Paolo Surico, Inflation Targeting and Nonlinear Policy Rules: The Case of Asymmetric Preferences, September 2004

1281 Ayal Kimhi, Growth, Inequality and Labor Markets in LDCs: A Survey, September 2004

1282 Robert Dur and Amihai Glazer, Optimal Incentive Contracts for a Worker who Envies his Boss, September 2004

1283 Klaus Abberger, Nonparametric Regression and the Detection of Turning Points in the Ifo Business Climate, September 2004

1284 Werner Güth and Rupert Sausgruber, Tax Morale and Optimal Taxation, September 2004

1285 Luis H. R. Alvarez and Erkki Koskela, Does Risk Aversion Accelerate Optimal Forest Rotation under Uncertainty?, September 2004

1286 Giorgio Brunello and Maria De Paola, Market Failures and the Under-Provision of Training, September 2004 